\title{
Synthesize of Poly (Acrylamide-Co-Itaconic/TiO2) Nanocomposite for Ce(III) Sorption from Monazite Leachate
}

Gehan AbdelRahman Dakrorury ( $\nabla$ dr_gdakrory2010@yahoo.com )

Egyptian Atomic Energy Authority https://orcid.org/0000-0003-0905-0672

Ragab mohasab Maree

Hot Laboratories Centre, Egyptian Atomic Energy Authority

Ehab Abu El Soud Abdel Halim El Shazly

Egyptian Atomic Energy Authority

Karam Fatwhi Allan

Egyptian Atomic Energy Authority

\section{Research Article}

Keywords: Acrylamide, Itaconic acid, TiO2, Sorption, Monazite, Cerium (III)

Posted Date: July 20th, 2021

DOI: https://doi.org/10.21203/rs.3.rs-722147/v1

License: (1) This work is licensed under a Creative Commons Attribution 4.0 International License.

Read Full License 


\section{Synthesize of poly (acrylamide-co-itaconic/ $\mathrm{TiO}_{2}$ ) nanocomposite for $\mathrm{Ce}$ (III) sorption} from monazite leachate

\section{Gehan AbdelRahman Dakroury ${ }^{{ }^{*}}$, Ragab MohasabMaree ${ }^{2}$, Ehab Abu El Soud Abdel Halim El Shazly ${ }^{1}$, Karam Fatwhi allan ${ }^{1}$}

${ }^{1}$ Nuclear Chemistry Department, Hot Laboratories Centre, Egyptian Atomic Energy Authority, Cairo, Egypt, P.O. 13759

${ }^{2}$ Radiation Protection Department, Hot Laboratories Centre, Egyptian Atomic Energy Authority, Cairo, Egypt, P.O. 13759

* Corresponding author address at e-mail:dr_gdakrory2010@yahoo.com

\section{Abstract:}

In this study, Acrylamide (AAM), Itaconic acid (IA) and nano $\mathrm{TiO}_{2}$ were copolymerized using gamma irradiation with ${ }^{60} \mathrm{Co} \gamma$-rays at a dose of $25 \mathrm{KGy}$ to form a novel nanocomposite; Poly(acrylamide-co-Itaconic acid/TiO $\left.{ }_{2}\right)\left(\mathrm{P}\left(\mathrm{AAM}-\mathrm{co}-\mathrm{IA} / \mathrm{TiO}_{2}\right)\right)$ for $\mathrm{Ce}(\mathrm{III})$ sorption from monazite leachate. $\mathrm{P}\left(\mathrm{AAM}-\mathrm{co}-\mathrm{IA} / \mathrm{TiO}_{2}\right)$ nanocomposite is characterized by different physicochemical techniques. The optimum $\mathrm{pH}$ for the sorption process at $298 \mathrm{~K}$ is 6 and the equilibrium attained after $60 \mathrm{~min}$. Different kinetics and isothermal models is applied. The monolayer adsorption capacity is $76.04 \mathrm{mgg}^{-1}$ at $298 \mathrm{~K}$. The sorption reaction follows a pseudo $-2^{\text {nd }}-$ order mechanism. The process is spontaneous and endothermic.

Keywords: Acrylamide; Itaconic acid; $\mathrm{TiO}_{2}$; Sorption; Monazite; Cerium (III)

\section{Introduction}

In the recent years, rare earth elements (REEs) have had important applications in industry as aerospace, electronic information and atomic energy [1-2]. Cerium and its derivatives are used extensively in metal alloys, glass, adsorbent, catalysts, and biomedical applications [3]. Monazite, lanthanide, xenotime, bastnaesite, allanite, loparite and phosphate rocks are all rich in REEs [4]. Cerium $(\mathrm{Ce})$ is the RE element with the highest concentration 
in light $\mathrm{RE}$ ores, $\mathrm{CeO}_{2} / \sum \mathrm{REO}$ in bastnaesite $(\mathrm{REFCO} 3)$ reaches 50 percent, while $\mathrm{CeO}_{2} /$ $\sum \mathrm{REO}$ in monazite $\left(\mathrm{REPO}_{4}\right)$ reaches $45-50 \%$ [5].

Various techniques for separating different lanthanides from aqueous solutions have been developed and used, including chemical precipitation [6], ion exchange extraction [7], coagulation[8], flocculation [9], liquid - liquid extraction [10], solid - phase extraction [11], biosorption [12] and classical sorption on different sorbents.

Various soils [13], montmorillonite nanoclay [14], HKUST-1 framework [15] and chert rocks [16] were used as sorbents for $\mathrm{Ce}(\mathrm{III})$ from aqueous solutions.

However, there is a still requirement for an efficient sorbent of low cost, selective, high sorption and desorption rates, better thermal stability and mechanical strength, easily regenerated which is the aim of this study.

Organic polymers as poly Acrylic acid, poly Malic acid, poly acrylamide and poly itaconic acid are well known for their uniformity and chemical stability. However, these materials have some drawbacks such as non-adequate mechanical strength and flexibility. Introduction of nano inorganic material as metal oxides to organic monomers to develop polymericinorganic nanocomposite greatly enhances its mechanical strength, toughness, glass transition temperature, optical and tensile strength, etc. $[17,18]$. The adsorption capacity of single polymers has been improved by copolymerization process.

Our study aims to prepare a novel nanocomposite for Ce(III) sorption from monazite leachate. Poly (acrylamide-co-Itaconic/ $\mathrm{TiO}_{2}$ ) nanocomposite prepared using gamma irradiation with ${ }^{60} \mathrm{Co} \gamma$-rays at a dose of $25 \mathrm{KGy}$. Characterization of P(AAM-co-IA/TiO ${ }_{2}$ performed by using FT-IR, DTA-TGA, SEM, particle size analysis, TEM and pore size distribution. Optimization of the parameters affecting sorption process like; $\mathrm{pH}$, contact time, 
metal ion concentration and sorbent weight carried out. The mechanism of the sorption reaction is proposed by applying different kinetic models and isotherm models. Finally, the prepared nanocomposite used as sorbent with optimum parameters for $\mathrm{Ce}$ (III) from monazite leachate.

\section{Experimental}

\subsection{Materials and procedure}

\subsubsection{Reagents}

All of the reagents utilized in this study were analytical grade and were not purified further. Acrylamide (AM) was supplied by Fuchen Chemical Co., Ltd., Tianjin, China. Methylene bis-acrylamide (DAM) and itaconic acid (IA) was used as polymeric monomers (Merck, Germany). Cerium (III) chloride heptahydrate $\left(\mathrm{CeCl}_{3} .7 \mathrm{H}_{2} \mathrm{O}\right)$ was puechased from Sigma Aldrich

The nuclear materials authority in Cairo, Egypt, provides monazite concentrate (monazite content of 90\%). Bidistilled water used For the composite's preparation, $\mathrm{pH}-$ normalization provided $(\mathrm{HCl})$ and $(\mathrm{NaOH})$. ADWIC (Egypt)

\subsubsection{Sorbent manufactured}

\subsubsection{Synthesized of nano $\mathrm{TiO}_{2}$}

$\mathrm{TiO}_{2}$ nanoparticles is synthesized by the sol-gel hydrolysis technique of titanium alkoxide [19]. The hydrolysed product gel is dried at $60^{\circ} \mathrm{C} / 48$ hours and used for the nanocomposite preparation.

\subsubsection{Synthesized of $\mathrm{P}\left(\mathrm{AAM}-\mathrm{M}-\mathrm{IA} / \mathrm{TiO}_{2}\right)$ nanocomposites}


To synthesize the $\mathrm{P}\left(\mathrm{AAM}-\mathrm{co}-\mathrm{IA} / \mathrm{TiO}_{2}\right)$ nanocomposites, different molar ratios of $\mathrm{AAM}$ and IA were copolymerized with nano $\mathrm{TiO}_{2}$ as shown in Table 1 in the presence of methylene bis acrylamide (DAM) as a cross-linker.

Acrylamide (AAM) is mixed with Itaconic acid (IA) and $\mathrm{TiO}_{2}$ nanoparticles in the presence of methylene bis acrylamide (DAM) in $50 \mathrm{ml}$ deoxygenated water. The mixture is stirred for 2 hours and ultrasonically treated for $10 \mathrm{~min}$. The details of the monomer compositions taken are given in Table (1). The mixture was subjected to gamma irradiation dose from a ${ }^{60} \mathrm{Co}$ unit at a dose $25 \mathrm{KGy}$. The materials were cut into small pieces and soaked in acetone for 2 hours to eradicate water and contaminants before being dried in a vacuum oven at $333 \mathrm{~K}$ for 24 hours and sieved to size $(<300 \mu \mathrm{m})$.

\subsubsection{Instruments}

The morphology of the particles investigated by scanning electron microscope combined with energy-dispersive X-ray spectroscopy and electron backscatter diffraction (SEM, Philips XL 30 ESEM (25-30 keV accelerating voltage, 1-2 mm beam diameter and 60-120 seconds counting time). The existence functional groups achieved by Fourier transform infrared spectra (FT-IR) ( KBr pellet technique on a Perkin Elmer 1600 FTIR Spectrophotometer in wave number range $600-4000 \mathrm{~cm}^{-1}$ ). The thermal stability of the composite determined by DTA-TGA analyses (Shimadzu DT- 60, Japan). The crystalline phase structure assigned by (XRD) (Philips X'PERT multipurpose X-ray diffractometer with copper emission lines). The concentration of REEs solutions is determined by Inductive Coupled Plasma Optical Emission Spectrometer type (Prodig Axial high dispersion ICP-OES model, USA and the 
concentration of $\mathrm{Ce}(\mathrm{III})$ is measured by an atomic absorption spectrophotometer (Buck Scientific, VGP 210).

\subsection{Sorption studies}

Sorption of $\mathrm{Ce}(\mathrm{III})$ onto the highest sorption efficiency $\mathrm{C} 6 \mathrm{P}\left(\mathrm{AAM}-\mathrm{co}-\mathrm{IA} / \mathrm{TiO}_{2}\right)$ nanocomposite studied. The optimum conditions for the sorption process maintained by variation of the reaction parameters. i.e. $\mathrm{pH}$ (2-7), contact time (15-120 minutes), initial concentration (50-500 $\left.\mathrm{mgL}^{-1}\right)$ and sorbent weight $(\mathrm{m}) .(0.05) \mathrm{g}$ of the sorbent contacted with $20 \mathrm{~mL}$ of the sorbate solution and after sorption time; samples were filtered and thus separated from the solution.

The Sorption efficiency of Ce(III) ions at each interval of time is given by equation (1):

$$
\text { Sorption efficiency }(\%)=\left(\frac{\mathrm{C}_{0}-\mathrm{C}_{\mathrm{f}}}{\mathrm{C}_{0}}\right) \times 100
$$

sorbed amount $\mathrm{q}\left(\mathrm{mgg}^{-1}\right)$ is calculated using equation (2):

$$
\mathrm{q}=\left(\mathrm{C}_{\mathrm{o}}-\mathrm{C}_{\mathrm{e}}\right) \frac{\mathrm{v}}{\mathrm{m}}
$$

Where $\mathrm{C}_{\mathrm{o}}, \mathrm{C}_{\mathrm{f}}$ and $\mathrm{C}_{\mathrm{e}}$ is the initial, final and equilibrium concentrations of the $\mathrm{Ce}(\mathrm{III})$ ions, respectively. $\mathrm{m}$ is the mass of the $\mathrm{C} 6 \mathrm{P}\left(\mathrm{AAM}-\mathrm{co}-\mathrm{IA} / \mathrm{TiO}_{2}\right)(\mathrm{g})$ and $\mathrm{V}$ volume of solution $(\mathrm{L})$.

\subsection{Kinetic modelling:}

Pseudo $1^{\text {st }}$ order, pseudo $2^{\text {nd }}$ order and Elovich model are applied through this work to arrive to a proposal for the mechanism of the sorption reaction.

The pseudo $1^{\text {st }}$ order equation is given by equation (3) [20]:

$$
\log \left(q_{e}-q_{t}\right)=\log q_{e}-\left(\frac{k_{1}}{2.303}\right) t
$$

Where $\mathrm{q}_{\mathrm{e}}$ and $\mathrm{q}_{\mathrm{t}}$ are the sorbed amounts of Ce(III) ions; $\left(\mathrm{mgg}^{-1}\right)$ at equilibrium time and at any time $\mathrm{t}$, respectively; $\mathrm{k}_{1}\left(\mathrm{~min}^{-1}\right)$ is the pesudo $1^{\text {st }}$ rate constant. 
The pseudo $2^{\text {nd }}$ order is described by the equation (4) [21]:

$$
\frac{t}{q_{t}}=\frac{1}{k_{2} q_{e}^{2}}+\frac{1}{q_{e}} t
$$

Where $\mathrm{k}_{2}\left(\mathrm{gmg}^{-1} \mathrm{~min}^{-1}\right)$ is the pseudo $2^{\text {nd }}$ order rate constant.

The surface coverage and activation energy are indicated in Elovich equation (5)[22]

$$
\mathrm{q}_{\mathrm{t}}=\frac{1}{\beta} \ln \alpha \beta+\frac{1}{\beta} \ln t
$$

Where the Elovich constants are $\alpha$ and $\beta . \alpha\left(\mathrm{mgg}^{-1} \mathrm{~min}^{-1}\right)$ is the rate of chemisorptions at zero coverage, whereas $\beta\left(\mathrm{gmg}^{-1}\right)$ is the extent of surface coverage and chemisorption activation energy.

\subsection{Isotherm Modelling}

Langmuir [23], Freundlich [24] and Temkin isotherm [25] are applied through this work

Langmuir isothermes model applied by equation (6)

$$
\frac{1}{q_{e}}=\frac{1}{Q}+\frac{1}{b Q}\left(\frac{1}{c_{e}}\right)
$$

Where $\mathrm{Q}$ is the monolayer sorption capacity $\left(\mathrm{mgg}^{-1}\right)$, b sorption free energy constant $\left(\mathrm{b} \alpha \mathrm{e}^{-}\right.$ $\Delta \mathrm{G} / \mathrm{RT}$ ) and $\mathrm{C}_{\mathrm{e}}$ is the metal ion concentration at equilibrium .

The free energy, $\Delta \mathrm{G}^{\mathrm{o}}$, was used to quantify the spontaneity of the sorption process. Negative $\Delta \mathrm{G}^{\mathrm{o}}$ values indicate that the sorption process is occurring spontaneously. Using the following Eq. (7), $\Delta \mathrm{G}^{\mathrm{o}}$, may be computed.

$$
\Delta G^{0}=-R T \ln K_{c}
$$


Where, $\mathrm{R}$ represents the general gas constant $\left(8.314 \mathrm{JK}^{-1} \mathrm{~mol}^{-1}\right)$, $\mathrm{T}$ represents the absolute temperature $(\mathrm{K})$, and $\mathrm{K}_{\mathrm{c}}$ represents the sorption equilibrium constant. The product of the Langmuir isotherm constant $\mathrm{Q}$ and $\mathrm{b}$ can be used to derive $\mathrm{K}_{\mathrm{c}}$ values. The following equation was used to derive the values of other thermodynamic parameters such as $\Delta \mathrm{H}^{\circ}$ and $\Delta \mathrm{S}^{\circ}$ :

$$
\ln K_{c}=\frac{\Delta S^{0}}{R}-\frac{\Delta H^{0}}{R T}
$$

The linear Eq.(9) represents Freundlich model

$$
\log \mathrm{q}_{\mathrm{e}}=\log \mathrm{K}_{\mathrm{f}}+\frac{1}{\mathrm{n}} \log \mathrm{C}_{\mathrm{e}}
$$

Where, $\mathrm{K}_{\mathrm{f}}$ denotes for Freundlich constants, and $\mathrm{n}$ denotes for sorption capacity and intensity.

Temkin considers that the sorption heat varies linearly with the degree of overlap. The following is the model: Eq. (10):

$$
\mathrm{q}_{\mathrm{e}}=\frac{R T}{b_{T}} \ln \left(\mathrm{A}_{\mathrm{T}} \mathrm{C}_{\mathrm{e}}\right)
$$

where $A_{T}$ is the maximal binding energy $\left(\mathrm{Lmol}^{-1}\right), b_{T}$ is the sorption heat, $R$ is the universal gas constant $\left(8.314 \mathrm{JK}^{-1} \mathrm{~mol}^{-1}\right)$, and $\mathrm{T}$ is the absolute temperature (K).

\subsection{Desorption studies}

The cost of the sorbent, its sorption efficiency, and its desorption ability are used to determine the success of the sorption process. The desorption behaviour of C6P(AAM-coIA/TiO 2 ) was investigated using three different concentrations of $\mathrm{HCl}, \mathrm{HNO}_{3}$, and acetic acid; $0.002 \mathrm{molL}^{-1}, 0.2 \mathrm{molL}^{-1}$, and $2 \mathrm{molL}^{-1}$ at $298 \mathrm{~K}$ for 24 hours. The mixture was filtered to separate the solid from the liquid phase, and the concentration of Ce(III) was then measured by atomic absorption spectrophotometer. The desorption percent percentage was calculated using equation (11): 
Where $C_{a q}$ is the concentration of $\mathrm{Ce}(\mathrm{III})$ in the aqueous phase and $C_{s}$ is the concentration of $\mathrm{Ce}(\mathrm{III})$ in the solid-phase.

\section{Result and discussion}

\subsection{Characterization of the prepared nanocomposite:}

\subsubsection{Zero Point charge:}

Zero point charge is defined as the $\mathrm{pH}_{\mathrm{pzc}}$ at which the charge on the surface is zero. The surface has a positive charge when the $\mathrm{pH}$ of the solution is less than $\mathrm{pH}_{\mathrm{pzc}}$, and a negative charge when the $\mathrm{pH}$ of the solution is more than $\mathrm{pH}_{\mathrm{pzc}}$. A small value of $\mathrm{pHpzc}$ is considered a sign of a good sorbent since it allows for a wide range of $\mathrm{pH}$ in its application for cation sorption.

$\mathrm{pH}_{\mathrm{pzc}}$ of $\mathrm{C} 6 \mathrm{P}\left(\mathrm{AAM}-\mathrm{co}-\mathrm{IA} / \mathrm{TiO}_{2}\right)$ nanocomposite was determined practically by modifying $\mathrm{pH}$ for a series of $50 \mathrm{ml}$ flasks, each of which contained $0.1 \mathrm{~g}$ of sorbent and $10 \mathrm{ml}$ of $0.01 \mathrm{molL}^{-1}(\mathrm{NaCl})$, and $\mathrm{pH}$ was varied from 1.0 to $12 .\left(\mathrm{pH}_{\text {initial }}\right)$. After shaking the mixture for 24 hours, the $\mathrm{pH}$ of the solutions was determined $\left(\mathrm{pH}_{\text {final }}\right)$. The $\mathrm{pH}_{\mathrm{pzc}}$ is then calculated by graphing $\mathrm{pH}_{\text {initial }}$ against $\Delta \mathrm{pH}\left(\mathrm{pH}_{\text {final }}-\mathrm{pH}_{\text {initial }}\right)$.

As shown in Fig. 1, the $\mathrm{pH}_{\mathrm{pzc}}$ of $\mathrm{C} 6 \mathrm{P}\left(\mathrm{AAM}-\mathrm{co}-\mathrm{IA} / \mathrm{TiO}_{2}\right)$ nanocomposite is 3.2. Cations sorption onto $\mathrm{C} 6 \mathrm{P}(\mathrm{AAM}-\mathrm{co}-\mathrm{IA} / \mathrm{TiO} 2)$ nanocomposite requires a $\mathrm{pH}$ greater than 3.2. At $\mathrm{pH}$ greater than 3.2, the carboxylic groups deprotonate, allowing negatively charged carboxylate ligands $\left(-\mathrm{COO}^{-}\right)$to bind $\mathrm{Ce}(\mathrm{III})$ ions. This suggests an ion exchange mechanism between negatively charged nanocomposite and positively charged nanocomposites. 


\subsubsection{Measurements of particle size}

The particle size of nano $\mathrm{TiO}_{2}$ particles are distributed in the range from 39 to $412 \mathrm{~nm}$ in Fig. 2a. More than $90 \%$ of $\mathrm{TiO}_{2}$ particles has nanocharacter. The incorporation of nanoparticles into a polymer can lead to a considerable improvement of mechanical properties [26]. However, the particles size of the composite increased in the range between 220-340 nm in Fig. 2b due to agglomeration of $\mathrm{TiO}_{2}$ nanoparticles and particle growth in the nanocomposite [27].

\subsubsection{SEM and TEM-analysis}

SEM of C6P(AAM-co-IA/ $\mathrm{TiO}_{2}$ ) nanocomposite shown in Fig .3a clarified the rough surface of the nanocomposite. This is due to the incorporation of the agglomerated $\mathrm{TiO}_{2}$ nanoparticles at the surface of the nanocomposite. The agglomeration of $\mathrm{TiO}_{2}$ nanoparticles is depicted in the TEM in Fig. 3b where the particle size of the nanoparticles is smaller than $50 \mathrm{~nm}$. This result seems to be less than that obtained by particle size measurements due to agglomeration of the particles. [28]. The agglomeration of $\mathrm{TiO}_{2}$ increases at the surface of the polymers leading to an increase in the particle size and this result confirmed by particle size measurements of C6P(AAM-co-IA/TiO 2 ) nanocomposite (Fig.3c).

\subsubsection{X-ray diffraction}

The amorphous nature of the nanocomposite is depicted from Fig. 4. The amorphous peaks intensities at, $2 \theta=25.16^{\circ}, 25.63^{\circ}, 36.08^{\circ}$ and $49.17^{\circ}$ confirm the presence of anatase 
phase of $\mathrm{TiO}_{2}$ Nanoparticles [29]. The amorphous character is due to the huge amounts of water content $\mathrm{C} 6 \mathrm{P}\left(\mathrm{AAM}-\mathrm{co}-\mathrm{IA} / \mathrm{TiO}_{2}\right)$ nanocomposite as a result of $-\mathrm{COOH}$ presence from Itaconic acid.

\subsubsection{FT-IR analysis}

Fig. 5 investigates the different molecular vibrations acquired by $\mathrm{C} 6 \mathrm{P}\left(\mathrm{AAM}-\mathrm{co}-\mathrm{IA} / \mathrm{TiO}_{2}\right)$ nanocomposite. A broad band from $3000-3600 \mathrm{~cm}^{-1}$ referred to $\mathrm{O}-\mathrm{H}$ stretching vibration band overlapping with N-H bending. The absorption bands at 2934, 1608 and $1412 \mathrm{~cm}^{-1}$ assigned to $-\mathrm{CH}_{2}$ stretching band, $\mathrm{O}-\mathrm{H}$ and $-\mathrm{COO}$ symmetric vibration band, respectively. The stretching vibration of carbonyl group $-\mathrm{C}=\mathrm{O}$ represented by the absorption band at $1666 \mathrm{~cm}^{-1}$. The amide group at $\mathrm{C} 6 \mathrm{P}\left(\mathrm{AAM}-\mathrm{co}-\mathrm{IA} / \mathrm{TiO}_{2}\right)$ nanocomposite is identified by the vibration stretching band $\mathrm{C}-\mathrm{N}$ at $1450 \mathrm{~cm}^{-1}$ and $1191 \mathrm{~cm}^{-1}$ for $-\mathrm{NH}_{2}$ bending vibration band [30]. The interaction between $\mathrm{TiO}_{2}$ Nanoparticles and AAM, IA is confirmed by the Ti-O-C deformation structure at $1120 \mathrm{~cm}^{-1}$ absorption band [31]. The bands at $775 \mathrm{~cm}^{-1}$ and $524 \mathrm{~cm}^{-1}$ were as a result of the Ti-O bond stretching mode of the $\mathrm{TiO}_{2}[30]$

\subsubsection{Thermal analysis}

The thermal stability of the prepared nanocomposite indicated in Fig.6 . A total 66\% of the total weight of the nanocomposite lost up to $600{ }^{\circ} \mathrm{C}$. Two endothermic peaks at $96.38^{\circ} \mathrm{C}$ and $233.4{ }^{\circ} \mathrm{C}$ with weight loss percentage $6.9 \%$ due to evaporation of physically adsorbed water and structural water, respectively. Three exothermic peaks at $409.8{ }^{\circ} \mathrm{C}, 459^{\circ} \mathrm{C}$ 
and $524^{\circ} \mathrm{C}$ due to degradation of $\mathrm{C} 6 \mathrm{P}\left(\mathrm{AAM}-\mathrm{co}-\mathrm{IA} / \mathrm{TiO}_{2}\right)$ nanocomposite and combustion of organic materials.

\subsubsection{Surface measurements}

The porous materials reveals its efficiency for sorption process. However, only open pores take a part in sorption process as active sites. The difference between Apparent density and bulk density express the extent of open pores in the sample. C6P(AAM-co-IA/ $\left.\mathrm{TiO}_{2}\right)$ nanocomposite has $\sim 27 \%$ porosity. The average pore diameter is $88 \mathrm{~nm}$ indicate macropores structure expecting an increase in sorption and desorption efficiency.

\subsection{Sorption study}

The sorption efficiency (\%) and distribution coefficients of $\mathrm{P}\left(\mathrm{AAM}-\mathrm{co}-\mathrm{IA} / \mathrm{TiO}_{2}\right)$ nanocomposites towards Ce(III) are given in Table 3. It is observed that sorption efficiencies $(\%)$ and distribution coefficient of $\mathrm{C} 6 \mathrm{P}\left(\mathrm{AAM}-\mathrm{co}-\mathrm{IA} / \mathrm{TiO}_{2}\right)$ composition show high sorption efficiency compared with the other compositions of the prepared samples. Thus, sample C6P(AAM-Co-IA/ $\mathrm{TiO}_{2}$ ) selected for the aim of the study.

\subsubsection{Effect of $\mathbf{p H}$ :}


Hydrogen ion concentration considers as an important parameter effecting the sorption reaction. In Figure 7a, the influence of $\mathrm{pH}$ on $\mathrm{Ce}(\mathrm{III})$ sorption onto C6P(AAM-co$\mathrm{IA} / \mathrm{TiO}_{2}$ ) nanocomposite is investigated in the range 2-7. It is indicated that the amount sorbed of $\mathrm{Ce}(\mathrm{III})$ is increased by increasing $\mathrm{pH}$ levels. When the $\mathrm{pH}$ is more than 6 , the sorption efficiency increase from $80.11 \%$ to $85 \%$ but $\mathrm{Ce}(\mathrm{III})$ precipitate, making it impossible to distinguish between the amount of $\mathrm{Ce}$ (III) sorbed onto the nanocomposite and the precipitated amount [32]. Therefore, the optimum $\mathrm{pH}$ value was maintained at $\mathrm{pH}=6$. As value of $\mathrm{pH}$ is less than 6 , the hydronium ion $\left[\mathrm{H}_{3} \mathrm{O}\right]^{+}$compete $\mathrm{Ce}(\mathrm{III})$ for occupying the active sites on $\mathrm{C} 6 \mathrm{P}\left(\mathrm{AAM}-\mathrm{co}-\mathrm{IA} / \mathrm{TiO}_{2}\right)$ nanocomposite surface and so the sorption of $\mathrm{Ce}(\mathrm{III})$ is decreased. Increasing $\mathrm{pH}$ value, decreasing concentration of $\left[\mathrm{H}_{3} \mathrm{O}\right]^{+}$, led to a decrease in the competition and so the sorption of $\mathrm{Ce}(\mathrm{III})$ onto the $\mathrm{C} 6(\mathrm{PAAM}-\mathrm{Co}-\mathrm{IA}) / \mathrm{TiO}_{2}$ nanocomposite is increased.

Figure $7 \mathrm{~b}$ shows the $\mathrm{Ce}(\mathrm{III})$ speciation diagram in aqueous solution at various $\mathrm{pH}$ levels. It demonstrates that $\mathrm{Ce}(\mathrm{III})$ ions are provided at the optimal $\mathrm{pH}$ of 6 , indicating that $\mathrm{Ce}(\mathrm{III})$ ions are trivalently sorbed. Hydroxides began to form at $\mathrm{pH}$ levels greater than 6 [33]. The distribution coefficient of $\mathrm{Ce}(\mathrm{III})$ at $298 \mathrm{~K}$ onto $\mathrm{C} 6 \mathrm{P}\left(\mathrm{AAM}-\mathrm{Ao}-\mathrm{IA} / \mathrm{TiO}_{2}\right)$ (Fig. 7c) increases as the $\mathrm{pH}$ increase at $\mathrm{V} / \mathrm{m}$ ratio 400 . This is owing to increase of the electrostatic attraction between the cerium ions and the surface of the composite.

\subsubsection{Impact of contact time}

The impact of contact time on sorption process studied at range (10-240 min) and represented in Fig. 8. The sorbed amount increases gradually till the equilibrium time of the sorption process which reached attained nearly at 60 minutes. The high sorption efficiency at 
the initial stage of the process owing to the great number of vacant active sites on the C6P(AAM-co-IA/ $\mathrm{TiO}_{2}$ ) surface as well as the high concentration of $\mathrm{Ce}(\mathrm{III})$ ion solution.

\subsubsection{Effect of sorbent weight}

Fig.9 includes the plot of $\mathrm{C} 6 \mathrm{P}\left(\mathrm{AAM}-\mathrm{co}-\mathrm{IA} / \mathrm{TiO}_{2}\right)$ nanocomposite weight against the sorption efficiency and the sorbed amount. The sorbed amount of Ce(III) onto C6P(AAM-co$\mathrm{IA} / \mathrm{TiO}_{2}$ ) nanocomposite increases from 44.47 to $88.80 \mathrm{mgg}^{-1}$ by increasing the weight of C6P(AAM-co-IA/ $\mathrm{TiO}_{2}$ ) nanocomposite from 0.01 to $0.1 \mathrm{~g}$ at an initial concentration of $\mathrm{Ce}$ (III) $200 \mathrm{mgL}^{-1}$. This is due to the fact that the sorption capacity influenced by surface activity. The increase in the amount of $\mathrm{C} 6 \mathrm{P}\left(\mathrm{AAM}-\mathrm{co}-\mathrm{IA} / \mathrm{TiO}_{2}\right)$ nanocomposite weight will increase specific surface area which increases the number of sorption sites available for Ce(III) surface interactions as well as increase in diffusion path length [34].

\subsubsection{Effect of metal ion concentration \&temperature}

Even if the sorbed amount increases, the sorption efficiency of C6P(AAM-co$\mathrm{IA} / \mathrm{TiO}_{2}$ ) decreases in percentage with raising original $\mathrm{Ce}(\mathrm{III})$ ion concentration. This is owing to the active sites on the sorbent becoming available at low Ce concentrations (III). The sorption effectiveness diminishes as the quantity of metal ion increases because the number of available binding sites reduces [35]. 
From the results shown in Fig.10 for the sorbed amount of Ce(III) onto C6P(AAMco-IA/ $\mathrm{TiO}_{2}$ ) nanocomposite at different temperatures at 298,308 , and $318 \mathrm{~K}$, it is obvious that the sorbed amount increases by raising the temperature due to acceleration of some originally slow sorption steps or due to the enhanced mobility of Ce(III) ions from the solution to the functionalized $\mathrm{C} 6 \mathrm{P}\left(\mathrm{AAM}-\mathrm{co}-\mathrm{IA} / \mathrm{TiO}_{2}\right)$ surface [36].

\subsection{Kinetic modelling}

Fig. $11 \mathrm{a}, \mathrm{b}$ shows the pseudo $1^{\text {st }}$ order and pseudo $2^{\text {nd }}$ order fitting plots. Table 4 contains the kinetic parameters. The identity value of $\mathrm{q}_{\mathrm{e}}$ (cal.) with the value of the experimental data $\mathrm{q}_{\mathrm{e}}$ (exp.) and the high $\mathrm{R}^{2}$ for pseudo $2^{\text {nd }}$ order for $\mathrm{Ce}(\mathrm{III})$ elucidate that the sorption of $\mathrm{Ce}(\mathrm{III})$ onto C6P(AAM-co-IA/ $\left.\mathrm{TiO}_{2}\right)$ nanocomposite controlled by pseudo $2^{\text {nd }}$ order mechanism. The pseudo $2^{\text {nd }}$ order reaction mechanism of C6P(AAM-co-IA/ $\left.\mathrm{TiO}_{2}\right)$ nanocomposite are synchronised. with chemisorption reaction and valence electrons sharing or ion exchange between $\mathrm{Ce}(\mathrm{III})$ and $\mathrm{H}^{+}[37]$.

Fig.11c shows the interpretation of Elvoich Eq. (5). The linear relation with correlation coefficient $\mathrm{R}^{2}=0.96$ accumulate for the agreement of the reaction mechanism with Elvoich and a good correlation for $\mathrm{C} 6 \mathrm{P}\left(\mathrm{AAM}-\mathrm{co}-\mathrm{IA} / \mathrm{TiO}_{2}\right)$ heterogeneous surface [38]. $\alpha$ and $\beta$ parameters listed in Table 4. 


\subsection{Isotherm models}

Fig.12a shows the linear plot of $\mathrm{C}_{\mathrm{e}} / \mathrm{q}_{\mathrm{e}}$ versus $\mathrm{C}_{\mathrm{e}}$ illustrating the sorption process fitted with Langmuir model with high correlation coefficient, $\mathrm{R}^{2}=0.99$. The values of the monolayer capacity, Q, at different temperatures were estimated from the slope and represented in Table 5. The sorption capacity of $\mathrm{Ce}(\mathrm{III})$ at $298 \mathrm{~K}$ onto C6P(AAM-co$\mathrm{IA} / \mathrm{TiO}_{2}$ ) nanocomposite is $76.05 \mathrm{mgg}^{-1}$. The sorption capacity increased with the temperature. The process is favourable because $0<\mathrm{R}_{\mathrm{L}}<1$

By graphing log qe versus $\log \mathrm{Ce}$, (Fig. 12b), straight lines were produced at different temperatures. The values of Freundlich constants, $1 / \mathrm{n}$ and $\mathrm{k}$, are determined from the slope and intercept, respectively, and given in Table 5.

The numerical of $n>1$ suggested that $\mathrm{C} 6 \mathrm{P}\left(\mathrm{AAM}-\mathrm{co}-\mathrm{IA} / \mathrm{TiO}_{2}\right)$ bind with a highest strength multiple binding sites of sorbent and the sorption capacities were only slightly inhibited in relative low equilibrium concentration. The correlation coefficients of the Langmuir isotherm model $\left(\mathrm{R}^{2}\right)$ were higher than those of the Freundlich isotherm model, indicating that the sorption process fits the Langmuir model better.

The constants of $\mathrm{A}_{\mathrm{T}}$ and $\mathrm{b}_{\mathrm{T}}$ for Temkin fitting determined from the slope and intercept of the plot of $\mathrm{q}_{\mathrm{e}}$ against $\ln \mathrm{C}_{\mathrm{e}}$ in Fig. 12c. These constants correlated to the sorption capacity and intensity of sorption. $\mathrm{R}^{2}$, correlation coefficient value is close to unity indicating the sorption mechanism which is governed by chemisorptions process confirming pseudo $2^{\text {nd }}$ order and Elvoich model. 


\subsection{Thermodynamic studies}

The slope and intercept of the plot of Fig. 13, according to Equations (7-8), can be used to derive the values of $\Delta \mathrm{H}^{\circ}$ and $\Delta \mathrm{S}^{\circ}$, respectively, represented in Table 6. The endothermic character of the sorption process is indicated by the positive value of $\Delta \mathrm{H}^{\circ}$, and the increase in randomness at the nanocomposite/solution interface is indicated by the positive value of $\Delta \mathrm{S}^{\circ}$. The negative value $\Delta \mathrm{G}^{\circ}$ indicates the sorption process is spontaneous. The increase in negative Gibbs free energy with increasing temperature indicates that the process is becoming more spontaneous. Furthermore, positive values of $\Delta S^{\circ}$ suggest that $\mathrm{Ce}(\mathrm{III})$ exchanges with mobile ions exist on $\mathrm{C} 6 \mathrm{P}\left(\mathrm{AAM}-\mathrm{co}-\mathrm{IA} / \mathrm{TiO}_{2}\right)$ nanocomposite, resulting in an increase in entropy value via the sorption process.

\subsection{Desorption studies}

Fig. 14 represents the variation of accessible desorption efficiency with the different concentration of acids. The percentage of desorption increased as the concentration of the 
acids increased. The order of desorption efficiency is $\mathrm{HCl}>\mathrm{HNO}_{3}>$ acetic acid and $2 \mathrm{molL}^{-}$

${ }^{1} \mathrm{HCl}$ is the most prober eluent for $\mathrm{Ce}(\mathrm{III})$ with $70.7 \%$ desorption efficiency.

\subsection{Comparison with other Ce(III) sorbents:}

The sorption capacity of $\mathrm{C} 6 \mathrm{P}\left(\mathrm{AAM}-\mathrm{co}-\mathrm{IA} / \mathrm{TiO}_{2}\right)$ nanocomposite toward $\mathrm{Ce}(\mathrm{III})$ is compared with other sorbents [39-44]. The results, illustrated in Table 7 shown that the C6P(AAM-co-IA/ $\mathrm{TiO}_{2}$ ) nanocomposite could be considered as a promising material to retain $\mathrm{Ce}(\mathrm{III})$.

\subsection{Sorption of $\mathrm{Ce}(\mathrm{III})$ from monazite leachate:}

Sorption of $\mathrm{Ce}(\mathrm{III})$ and some rare earth ions $\left(\mathrm{RE}^{3+}\right)$ onto $\mathrm{C6P}\left(\mathrm{AAM}-\mathrm{co}-\mathrm{IA} / \mathrm{TiO}_{2}\right)$ nanocomposite is measured using inductive coupled plasma optical emission spectrometer. $0.14 \mathrm{~g}$ of $\mathrm{C} 6 \mathrm{P}\left(\mathrm{AAM}-\mathrm{co}-\mathrm{IA} / \mathrm{TiO}_{2}\right)$ contacting with $20 \mathrm{~mL}$ of the monazite leachate solution at $298 \mathrm{~K}$ and $\mathrm{pH}$ 6. The results for energy dispersive X-ray spectra of loaded C6P(AAM-co$\mathrm{IA} / \mathrm{TiO}_{2}$ ) is shown in Fig. 15. The spectrum shows $\mathrm{La}, \mathrm{Ce}, \mathrm{Eu}, \ldots$ bands besides $\mathrm{C}, \mathrm{O}, \mathrm{N}$, and $\mathrm{Na}$ consistent with the elemental formula of monazite[44] and nanocomposite. The roughness of the surface of $\mathrm{C} 6 \mathrm{P}\left(\mathrm{AAM}-\mathrm{co}-\mathrm{IA} / \mathrm{TiO}_{2}\right)$ at the end of the sorption processes as depicted in Fig 15. Furthermore, the mapping images of loaded C6P(AAM-co-IA/TiO $\left.{ }_{2}\right)$ nanocomposite with REEs indicate that REEs ions are adequately adsorbed at the surface of the nanocomposite and they are distributed uniformly. $\mathrm{La}, \mathrm{Ce}$ and $\mathrm{Eu}$ are taken as examples of REEs to confirm sorption process. Table 8 includes the sorption efficiency and desorption percentage of light rare earth ions $\left(\mathrm{LRE}^{3+}\right)$ and heavy rare earth ions $\left(\mathrm{HRE}^{3+}\right)$ onto C6P(AAM-co-IA/TiO 2 nanocomposite. The results show a sorption selectivity for C6P(AAM-co-IA/TiO 2 ) nanocomposite towards $\mathrm{HRE}^{3+}$ where the sorption efficiency is 
$70.94 \%$ compared to $54.09 \%$ for $\mathrm{LRE}^{3+}$. Thus, C6P(AAM-co-IA/TiO 2 ) nanocomposite could be used for group partial separation of $\mathrm{LRE}^{3+}$ than $\mathrm{HRE}^{3+}$. The desorption percentage shows any selectivity for $\mathrm{RE}^{3+}$, as both $\mathrm{LRE}^{3+}$ and $\mathrm{HRE}^{3+}$ have similar desorption percentage. Ce(III) shows $61.62 \%$ sorption for the initial concentration at monazite leachate 577.652 $\mathrm{mgL}^{-1}$. The sorption efficiency for Ce(III) decreased in single component system than in multicomponent system in case of monazite leachate solution these is due to selectivity of C6P(AAM-co-IA/TiO 2 ) nanocomposite towards $\mathrm{HRE}^{3+}$ possessing low ionic radii [45]. 0 1

2

\section{Conclusion}

Poly(acrylamide -co- Itaconic acid/ $\left.\mathrm{TiO}_{2}\right)\left(\mathrm{P}\left(\mathrm{AAM}-\mathrm{co}-\mathrm{IA} / \mathrm{TiO}_{2}\right)\right)$ nanocomposite is successfully prepared by copolymerization of Acrylamide (AAM), Itaconic acid (IA) and nano $\mathrm{TiO}_{2}$ using gamma irradiation with ${ }^{60} \mathrm{Co} \gamma$-rays at a dose of $25 \mathrm{KGy}$. Characterization of the prepared samples performed by different analytical techniques. C6P(AAM-co-IA/ $\left.\mathrm{TiO}_{2}\right)$ used as a sorbent for $\mathrm{Ce}(\mathrm{III})$ from monazite leachate. Optimization of the parameters affecting sorption process is carried out. The equilibrium sorption reaction achieved after about $60 \mathrm{~min}$. The sorption process has endothermic nature; the results indicated that, the sorption reaction is regulated by pseudo- $2^{\text {nd }}$ order mechanism. The experimental equilibrium data tested for Langmuir and Freundlich isotherm. The monolayer capacity of $\mathrm{Ce}$ (III) onto $\mathrm{C} 6\left(\mathrm{P}\left(\mathrm{AAM}-\mathrm{co}-\mathrm{IA} / \mathrm{TiO}_{2}\right)\right)$ at $298 \mathrm{~K}, \mathrm{pH}=6$ is $76.05 \mathrm{mgg}^{-1}$. Using $\mathrm{C} 6\left(\mathrm{P}\left(\mathrm{AAM}-\mathrm{co}-\mathrm{IA} / \mathrm{TiO}_{2}\right)\right)$ nanocomposite as a sorbent for $\mathrm{Ce}$ (III) in multicompnent system of monazite leacate shows sorption efficiency $61.62 \%$ for $577.652 \mathrm{mgL}^{-1}$ initial concentration. Therefore, the prepared $\mathrm{C} 6\left(\mathrm{P}\left(\mathrm{AAM}-\mathrm{co}-\mathrm{IA} / \mathrm{TiO}_{2}\right)\right.$ ) nanocomposite can be considered as a promising material for the sorption of $\mathrm{Ce}(\mathrm{III})$. 
Declarations:

Funding: The authors received no financial support for the research, authorship, and/or publication of this article.

Conflict of interest: The authors declare that they have no conflict of interest.

Availability of data and material All the data used for this work are publicly available.

Research involving human participants and/or animals: Not applicable

Code availability not applicable

Ethical approval: The authors confirm that the manuscript has been read and approved by all authors. The authors declare that this manuscript has not been published and not under consideration for publication elsewhere.

Consent to participate: All of the authors consented to participate in the drafting of this manuscript

Consent for publication: All of the authors consent to publish this manuscript.

Author contributions: Gehan Dakroury, Ragab Mohasb Maree, Ehab El Shazly and Karam Allan contributed to the study conception and design, Material preparation, data collection and analysis. All authors read and approved the final manuscript.

\section{Author information}

Affiliations

Nuclear Chemistry Department, Hot Laboratories Centre, Egyptian Atomic Energy Authority, Cairo, Egypt, P.O. 13759

Gehan AbdelRahman Dakroury, , Ehab Abu El Soud Abdel Halim El Shazly, Karam allan Fatwhy

Radiation Protection Department, Hot Laboratories Centre, Egyptian Atomic Energy Authority, Cairo, Egypt, P.O. 13759

Ragab Mohasab Maree

\section{Corresponding Author}

Correspondence to Gehan AbdelRahman Dakroury

Tel: 00201100055344 
Fax: 0020244620784

dr_gdakrory2010@yahoo.com

\section{Reference:}

1. B. Grunert, J. Saatz, K. Hoffmann, F. Appler, D. Lubjuhn, N. Jakubowski, N. Jakubowski, U. Resch-Genger, F. Emmerling, A. Briel, Multifunctional Rare-Earth Element Nanocrystals for Cell Labeling and Multimodal Imaging. ACS Biomaterials Science \& Engineering. 4(2018) http://doi.org/10.1021/acsbiomaterials.8b00495

2. K. Binnemans, P.T. Jones, B. Blanpain, T. Van Gerven, Y. Yang, A. Walton, M. Buchert, Recycling of rare earths: a critical review. J. of Cleaner Production. 51, 122(2013) http://doi.org/10.1016/j.jclepro.2012.12.037

3. F. J. Alguacil, I. García-Díaz, E. B. Escudero, O. L. Rodríguez, A.F. López, On the Adsorption of Cerium(III) Using Multiwalled Carbon Nanotubes. Metals. 10, 1057(2020) http://doi.org/10.3390/met10081057

4. K.M. Goodenough, F. Wall, D. Merriman, The rare earth elements: Demand, Global Resources, and Challenges for Resourcing Future Generations. Natural Resourses Research. 27, 201-216 (2018) https://doi.org/10.1007/s11053-017-9336-5

5. K. Li, J. Chen, D. Zou, Extraction and Recovery of Cerium from Rare Earth Ore by Solvent Extraction, Cerium Oxide - Applications and Attributes (2019) http://doi.org/10.5772/intechopen.79225

6. K.Han, Characteristics of Precipitation of Rare Earth Elements with Various Precipitants. Minerals. 10, 178 (2020) http://doi.org/10. 178. 10.3390/min10020178 .

7. F. H. Spedding, A. F. Voigt, E. M. Gladrow, and N. R. Sleight, The Separation of Rare Earths by Ion Exchange. ${ }^{1,2}$ I. Cerium and Yttrium. J. of the American Chemical Society. 69 , 2777-2781(1947) http://doi.org/10.1021/ja01203a058

8. G.Song, X. Wang, C. Romero, H. Chen, Z.Yao, A.Kaziunas, R.Schlake, M. Anand, T. Lowe, G. Driscoll, B. Kreglow, H. Schobert, J. Baltrusaitis, Extraction of selected rare earth elements from anthracite acid mine drainage using supercritical $\mathrm{CO}_{2}$ via coagulation and complexation. Journal of Rare Earths. 39, 83-89(2020) https://doi.org/10.1016/j.jre.2020.02.007 
9. M. Yu, G. Mei, Y. Li et al. Recovering rare earths from waste phosphors using froth flotation and selective flocculation. Mining. Metallurgy \& Exploration. 34, 161-169 (2017) https://doi.org/10.19150/mmp.7855

10. 10. P.K. Parhi, K.H. Park, C.W. Nam, J.T. Park, Liquid-liquid extraction and separation of total rare earth (RE) metals from polymetallic manganese nodule leaching solution. Journal of Rare Earths. 33, 207-213(2015) https://doi.org/10.1016/S1002-0721

11. Z. Jiangyi, X. Wang, Y. Dong, Z. Xu, G. Li, Solid Phase Extraction of Rare Earth Elements in Deep Groundwater With Multi-wall Carbon Nanotubes as Adsorbent for the Determination by Inductively Coupled Plasma Mass Spectrometry. Atomic Spectroscopy. 37, 1-6 (2016) http://doi.org/10.46770/AS.2016.01.001 .

12. E.C. Giese, Biosorption as green technology for the recovery and separation of rare earth elements. World. J. Microbiol Biotechnol. 36, 52 (2020) . https://doi.org/10.1007/s11274-020-02821-6

13. M. Jiménez-Reyes, P.T. Almazán-Sánchez, M. Solache-Ríos, Behaviour of cerium(III) in the presence of components of soils and its humate complex. Environ. Technol. in press , 1-9 (2020) https://doi.org/10.1080/09593330.2020.1758219

14. F. Parisi, G. Lazzara, M. Merli, S. Milioto, F. Princivalle, L. Sciascia, Simultaneous removal and recovery of metal ions and dyes from wastewater through montmorillonite clay mineral. Nanomaterials. 9, 1699 (2019) http://doi.org/10.3390/nano9121699

15. L. Zhao, M.R. Azhar, X. Li, X. Duan, H. Sun, S. Wang, X. Fang, Adsorption of cerium (III) by HKUST-1 metal-organic framework from aqueous solution. J. Colloid Interface Sci. 542, 421-428(2019) https://doi.org/10.1016/j.jcis.2019.01.117

16. I. Bouchmila, B. Bejaoui Kefi, R. Souissi, M. Abdellaoui, Purification, characterization and application of cherty rocks as sorbent for separation and preconcentration of rare earths. J. Mater. Res. Technol. 8, 2910-2923(2019) https://doi.org/10.1016/j.jmrt.2018.10.018 
17. K.G. Varshney, N. Tayal, A.A. Khan, R. Niwas, Synthesis, characterization and analytical applications of lead(II) selective polyacrylonitrile thorium(IV) phosphate: a novel fibrous ion exchanger. Colloids and Surfaces A: Physicochemical and Engineering Aspects. 181, 123-129 (2001) https://doi.org/10.1016/S0927-7757(00)00750-0

18. S.R.V.S. Prasanna, K. Balaji, S. Pandey, S. Rana, Metal Oxide Based Nanomaterials and Their Polymer Nanocomposites. Nanomaterials and Polymer Nanocomposites, 123144, (2019) http://doi.org/10.1016/b978-0-12-814615-6.00004-7

19. G.A. Dakroury., S.F. Abo-Zahra, The use of titanium oxide/polyethylene glycol nanocomposite in sorption of ${ }^{134} \mathrm{Cs}$ and ${ }^{60} \mathrm{Co}$ radionuclides from aqueous solutions. $\mathrm{J}$ Radioanal Nucl Chem. 324, 1351-1364 (2020) https://doi.org/10.1007/s10967-020$\underline{07167-9}$

20. S.Lagergren, . About the theory of so-called adsorption of soluble substance. Kungliga Svenska Vetenskaps-Akademiens Handlingar. 24, 1-39 (1898)

21. G. McKay, Y. Ho, Pseudo-second order model for sorption processes. Process Biochem. 34, 461-465(1999) https://doi.org/10.1016/S0032-9592(98)00112-5

22. C.W. Cheung, J.F. Porter, G. Mckay, Sorption kinetics for the removal of copper and zinc from effluents using bone char. Sep Purif Technol.19, 55-64 (2000) 10.1016/S1383$\underline{5866(99) 00073-8}$

23. I. Langmuir, The adsorption of gases on plane surfaces of glass, mica and platinum. $\mathbf{J}$ Am Chem Soc. 40, 1361-1403(1918) https://doi.org/10.1021/ja02242a004

24. E. Weidner, F. Ciesielczyk, Removal of hazardous oxyanions from the environment using metal-oxide-based materials. Mater. $12 \quad, 927 \quad$ (2019) https://doi.org/10.3390/ma12060927

25. K. Vijayaraghavan, T. V. N. Padmesh, K. Palanivelu, M. Velan, Biosorption of nickel(II) ions onto Sargassum wightii: application of two-parameter and three-parameter isotherm models. Journal of Hazardous Materials. 133, 304-308 (2006) https://doi.org/10.1016/j.jhazmat.2005.10.016 
26. H. Salehian, S.A. Jenabali Jahromi, Effect of titanium dioxide nanoparticles on mechanical properties of vinyl ester-based nanocomposites. J. Composite Materials. 49, 2365-2373 (2015) http://doi.org/10.1177/00219983145461410

27. M.A. Ashraf, W. Peng, Y. Zare, K.Y.Rhee, Effects of Size and Aggregation/Agglomeration of Nanoparticles on the Interfacial/Interphase Properties and Tensile Strength of Polymer Nanocomposites. Nanoscale Res Lett. 13,214(2018) https://doi.org/10.1186/s11671-018-2624-0

28. W. Kangwansupamonkon, N. Klaikaew, S. Kiatkamjornwong, Green synthesis of titanium dioxide/acrylamide-based hydrogel composite, self degradation and environmental Applications. European Polymer Journal. 107, 118-131(2018) http://doi.org/10.1016/j.eurpolymj.2018.08.004

29. M. Dhayal, R. Kapoor, P.G. Sistla , R.R. Pandey, S. Kar, K.K.Saini, G.Pande, Strategies to prepare $\mathrm{TiO}_{2}$ thin films, doped with transition metal ions that exhibit specific physicochemical properties to support osteoblast cell adhesion and proliferation. Materials Science and Engineering C: Materials for Biological Applications. 37, 99107(2014) https://doi.org/10.1016/j.msec.2013.12.035

30. T. Qunwei, L. Jianming, W. Zibao, W. Jihuai, H. Miaoliang, Y. Yuanyuan, Preparation and photocatalytic degradability of $\mathrm{TiO}_{2} /$ polyacrylamide composite. European Polymer Journal. 43 ,

2214-2220 (2007) http://doi.org/10.1016/j.eurpolymj.2007.01.054

31. D. Dodoo-Arhin, F.P. Buabeng, J.M. Mwabora, P.N. Amaniampong, H. Agbe, E. Nyankson, ' D.O. Obada, N. Y. Asiedu, The effect of titanium dioxide synthesis technique and its photocatalytic degradation of organic dye pollutants. Heliyon. 4, (2018) . http://doi.org/10.1016/j.heliyon.2018.e00681

32. N. Chiron, R. Guilet, E. Deydier, Adsorption of $\mathrm{Cu}$ (II) and $\mathrm{Pb}$ (II) onto a grafted silica: isotherms and kinetic models. Water Res. 37, 3079-3086 (2003) https://doi.org/10.1016/S0043-1354(03)00156-8 
33. I.Puigdomenech Make equilibrium diagrams using sophisticated algorithms (MEDUSA), Inorganic Chemistry. Royal Institute of Technology, Stockholm Sweden, (2013) https:// www.kemi.kth.se/medusa, https://sites.google.com/site/chemdiagr.

34. R.M. Ali, H.A.Hamad, M.M. Hussein, G.F. Malash, Potential of using green adsorbent of heavy metal removal from aqueous solutions: adsorption kinetics, isotherm, thermodynamic, mechanism and economic analysis. Eco Eng. 91, 317-332(2016) https://doi.org/10.1016/j.ecoleng.2016.03.015

35. S. Ranote, B. Ram, D. Kumar, G.S. Chauhan, Ghanshyam, V. Joshi, Functionalization of Moringa oleifera gum for use as $\mathrm{Hg}^{2+}$ ions adsorbent. J. Environmental Chemical Engineering. 6, 1805-1813 (2018) http://doi.org/10.1016/j.jece.2018.02.032 .

36. N. Ferrah, O. Abderrahim, M.A. Didi, D. Villemin, Sorption Efficiency of a New Sorbent towards Cadmium(II): Methylphosphonic Acid Grafted Polystyrene Resin. J. Chemistry. 2013, 1-10 (2013) https://doi.org/10.1155/2013/980825

37. S. Jellali, M.A. Wahab, M. Anane, K. Riahi, N. Jedidi Biosorption characteristics of ammonium from aqueous solutions onto Posidonia oceanica (L.) fibers. Desalination. 270, 40-49 (2011) https://doi.org/10.1016/j.desal.2010.11.018

38. F.C. Wu, R.L. Tseng, R.S. Juang, Characteristics of Elovich Equation Used for the Analysis of Adsorption Kinetics in Dye-Chitosan Systems. Chemical Engineering Journal. 150, 366-373 (2009) http://doi.org/10.1016/j.cej.2009.01.014 .

39. Y.A. Akbas, S. Yusan, S. Sert, S. Aytas, Sorption of Ce(III) on magnetic/olive pomace nanocomposite: isotherm, kinetic and thermodynamic studies. Environ Sci Pollut Res (2021). https://doi.org/10.1007/s11356-021-14662-3

40. R. Zare-Dorabei, V. Jalalat, A. Tadjarodi, Central composite design optimization of $\mathrm{Ce}(\mathrm{iii})$ ion removal from aqueous solution using modified SBA-15 mesoporous silica. New J. Chemistry. 40, 5128-5134 (2016) http://doi.org/10.1039/c6nj00239k 
41. G. Wójcik, Sorption Behaviors of Light Lanthanides(III) (La(III), Ce(III), Pr(III), $\mathrm{Nd}(\mathrm{III}))$ and $\mathrm{Cr}(\mathrm{III}) \quad$ Using Nitrolite. Materials. 13, 2256(2020) http://doi.org/10.3390/ma13102256

42. M.A.K.M. Hanafiah, Z.M. Hussin, N.F.M. Ariff, W.S.W. Ngah, S.C. Ibrahim, Monosodium Glutamate Functionalized Chitosan Beads for Adsorption of Precious Cerium Ion. Advanced Materials Research. 970, 198-203(2014) https://doi.org/10.4028/www.scientific.net/amr.970.198

43. C. Yao, Adsorption and desorption properties of D151 resin for Ce(III). J. Rare Earths. 28, 183 - 188 (2013) http://dx.doi.org/10.1016/S1002-0721(10)60324-9

44. M. Torab-Mostaedi, M. Asadollahzadeh, A. Hemmati, A. Khosravi, Biosorption of lanthanum and cerium from aqueous solutions by grapefruit peel: equilibrium, kinetic and thermodynamic studies. Research on Chemical Intermediates. 41, 559- 573(2015) http://doi.org/10.1007/s11164-013-1210-4 1-15

45. S. Iftekhar, D.L. Ramasamy, V. Srivastava, M.B. Asif, M. Sillanpää, Understanding the factors affecting the adsorption of Lanthanum using different adsorbents: A critical review. Chemosphere. 204, 413-430 (2018) http://doi.org/10.1016/j.chemosphere.2018.04.053 
Figures

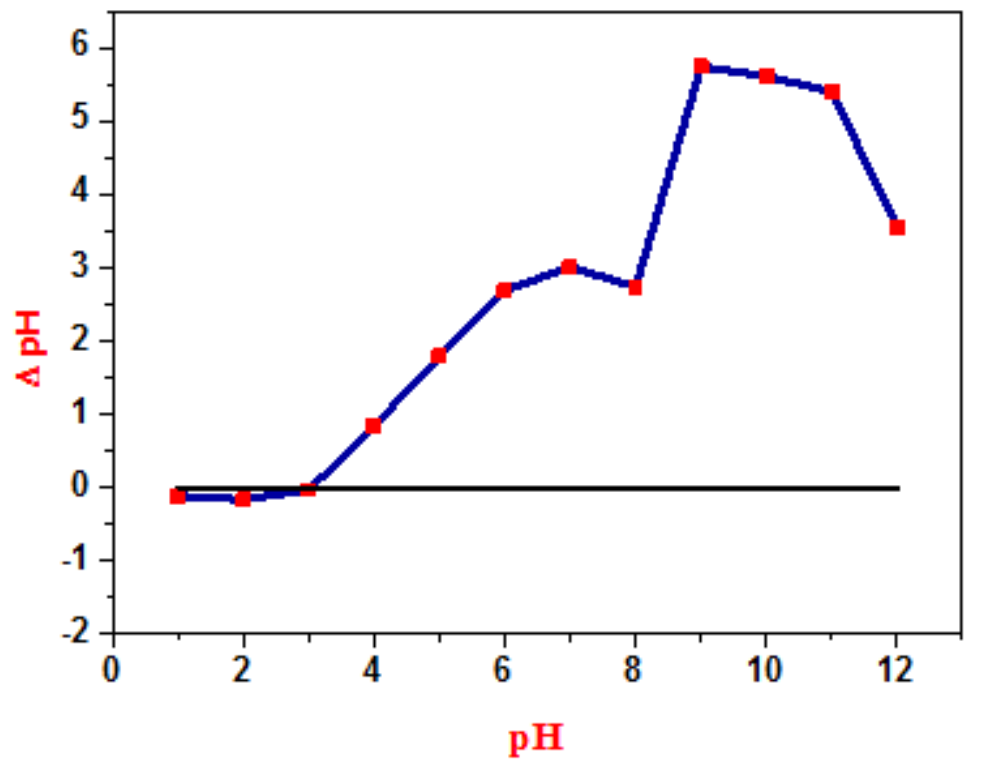

Figure 1

Determination of pHpzc for C6P(AAM-co-IA/TiO2 ) nanocomposite [using $0.1 \mathrm{~g}$ of the C6P(AAM-coIA/TiO2 ) nanocomposite with $10 \mathrm{ml}$ of $0.01 \mathrm{molL}-1 \mathrm{NaCl}$ at $298 \mathrm{~K}]$
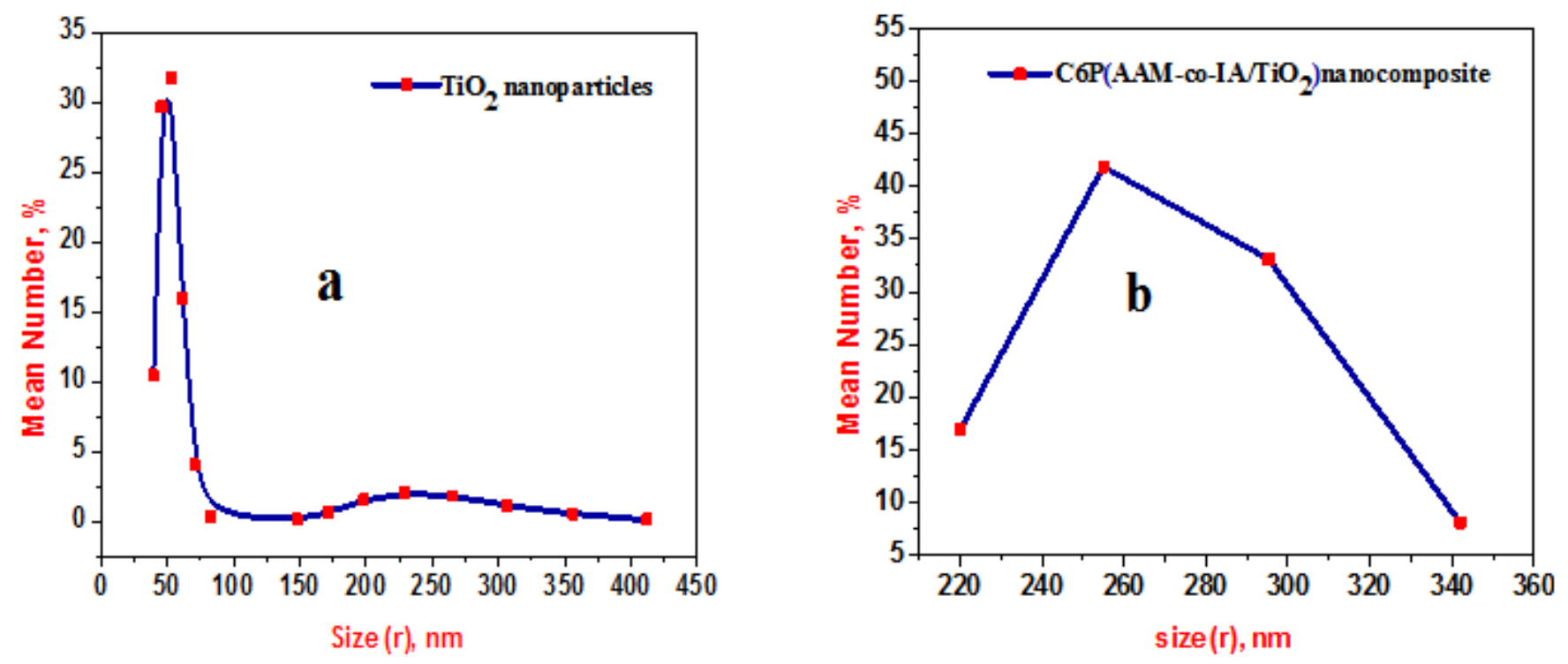

Figure 2

Particle size of a- TiO2 nanoparticles b- C6P(AAM-co-IA/TiO2) nanocomposite using distilled water as dispersing media 

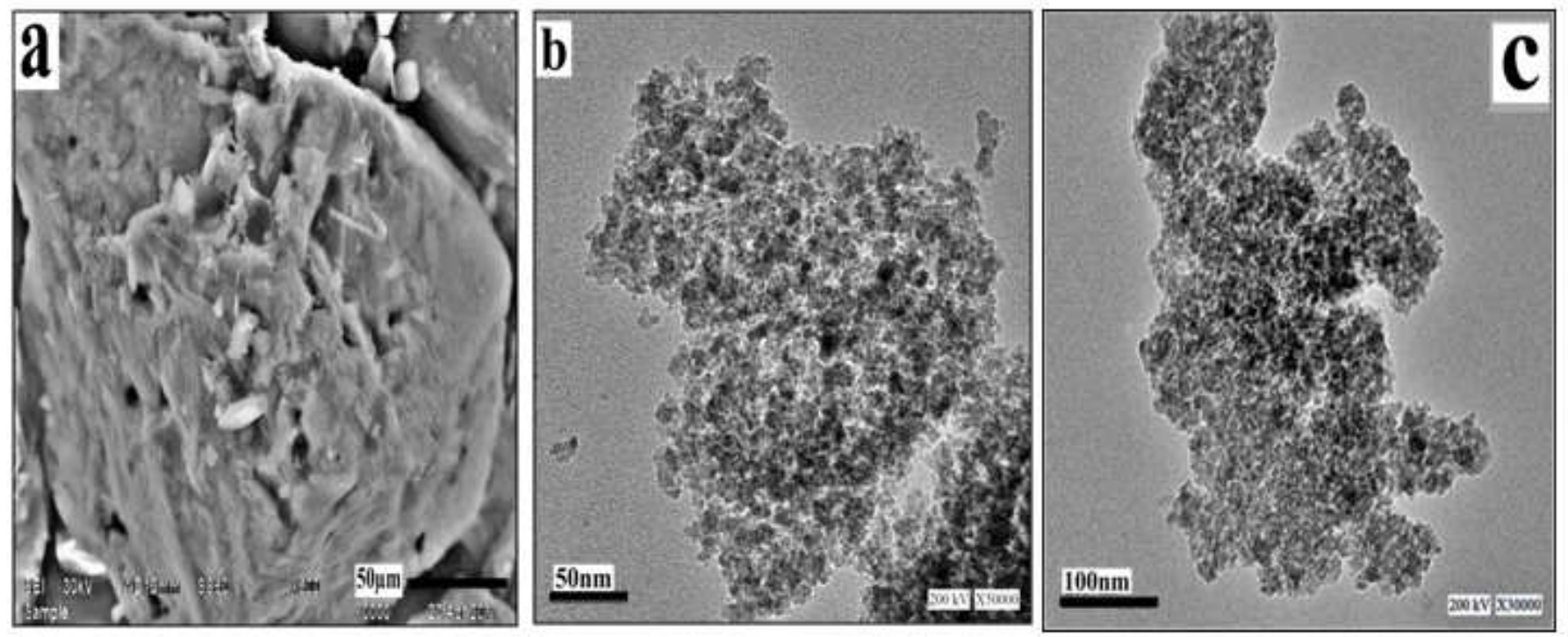

\section{Figure 3}

a- SEM of C6P(AAM-co-IA/TiO2) nanocomposite b- TEM of TiO2 nanoparticles c- TEM of C6P(AAM-coIA/TiO2) nanocomposite.

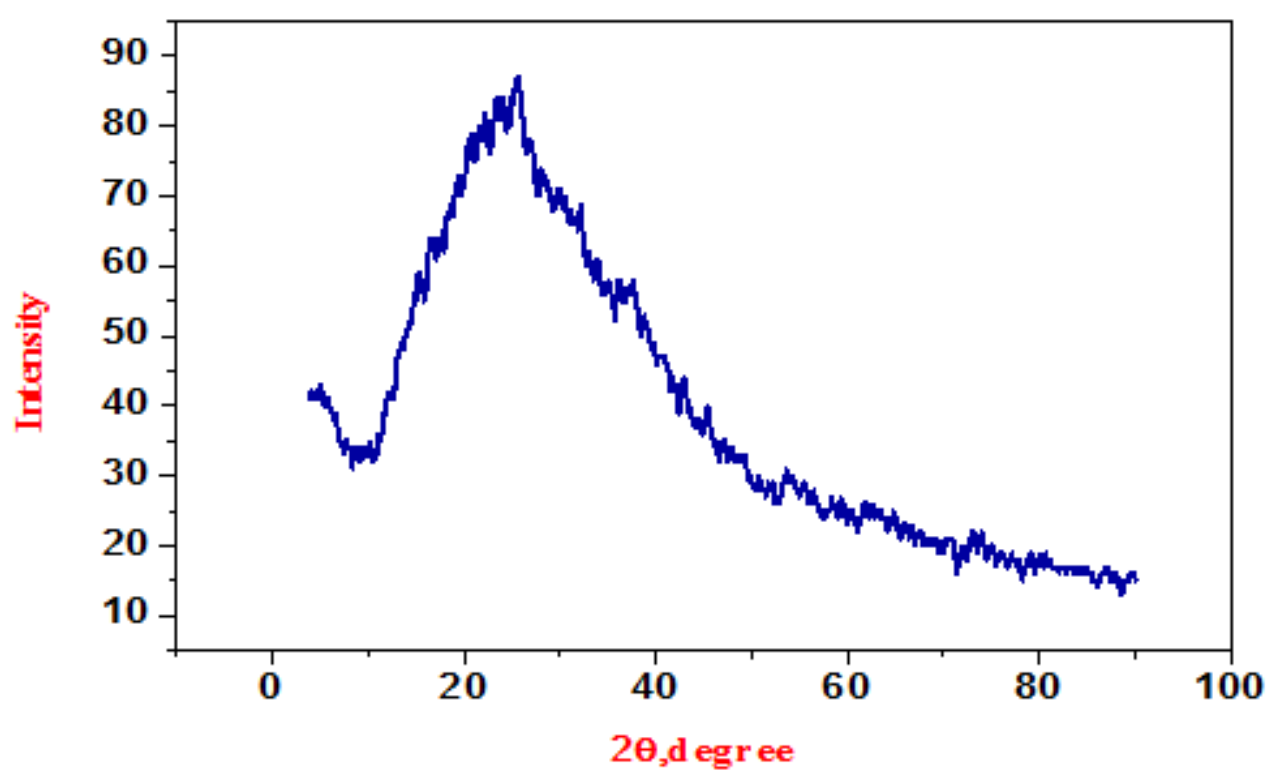

Figure 4

X-ray diffraction of C6P(AAM-co-IA/TiO2) nanocomposite 


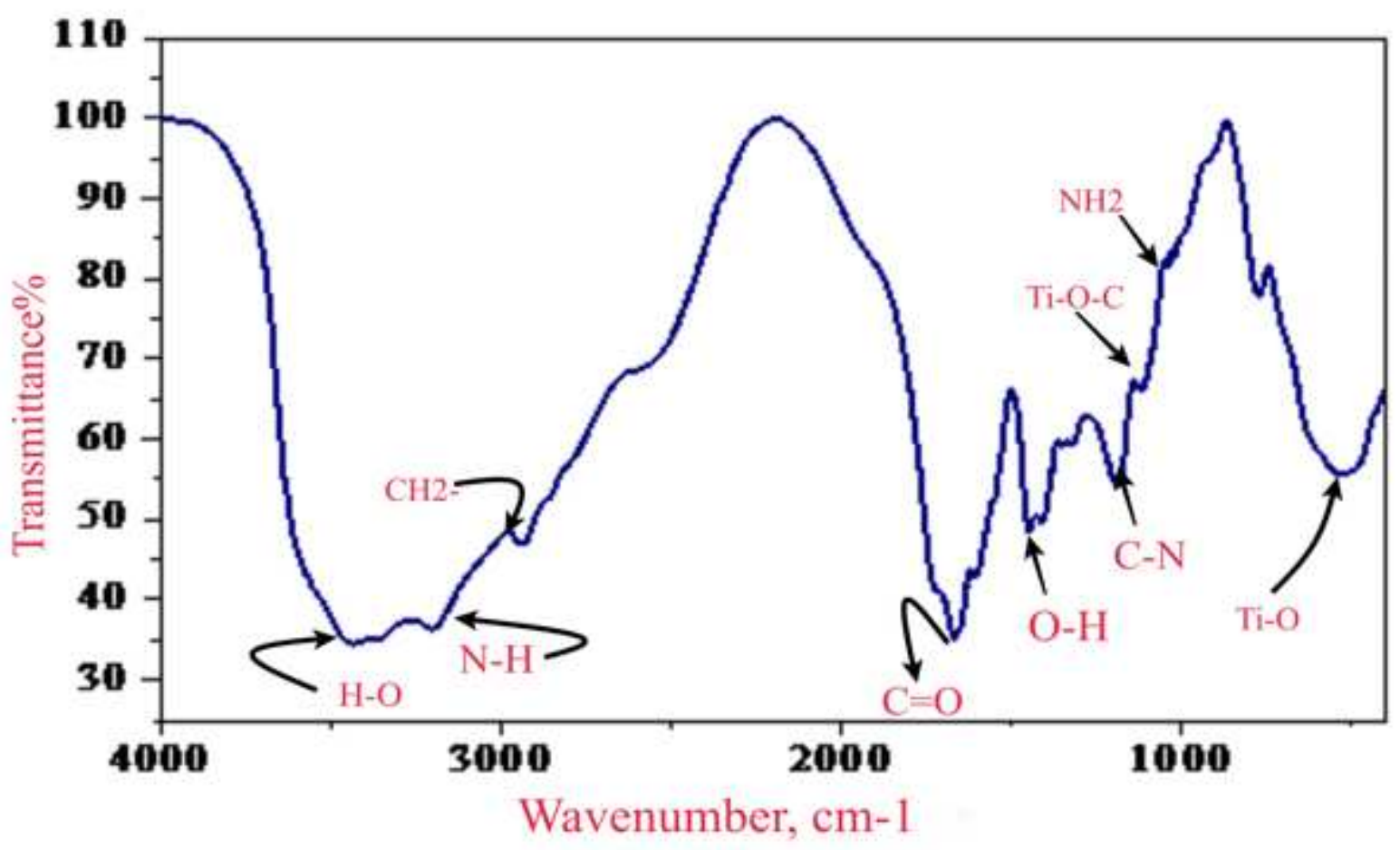

Figure 5

FT-IR spectrum of C6P(AAM-co-IA/TiO2) nanocomposite

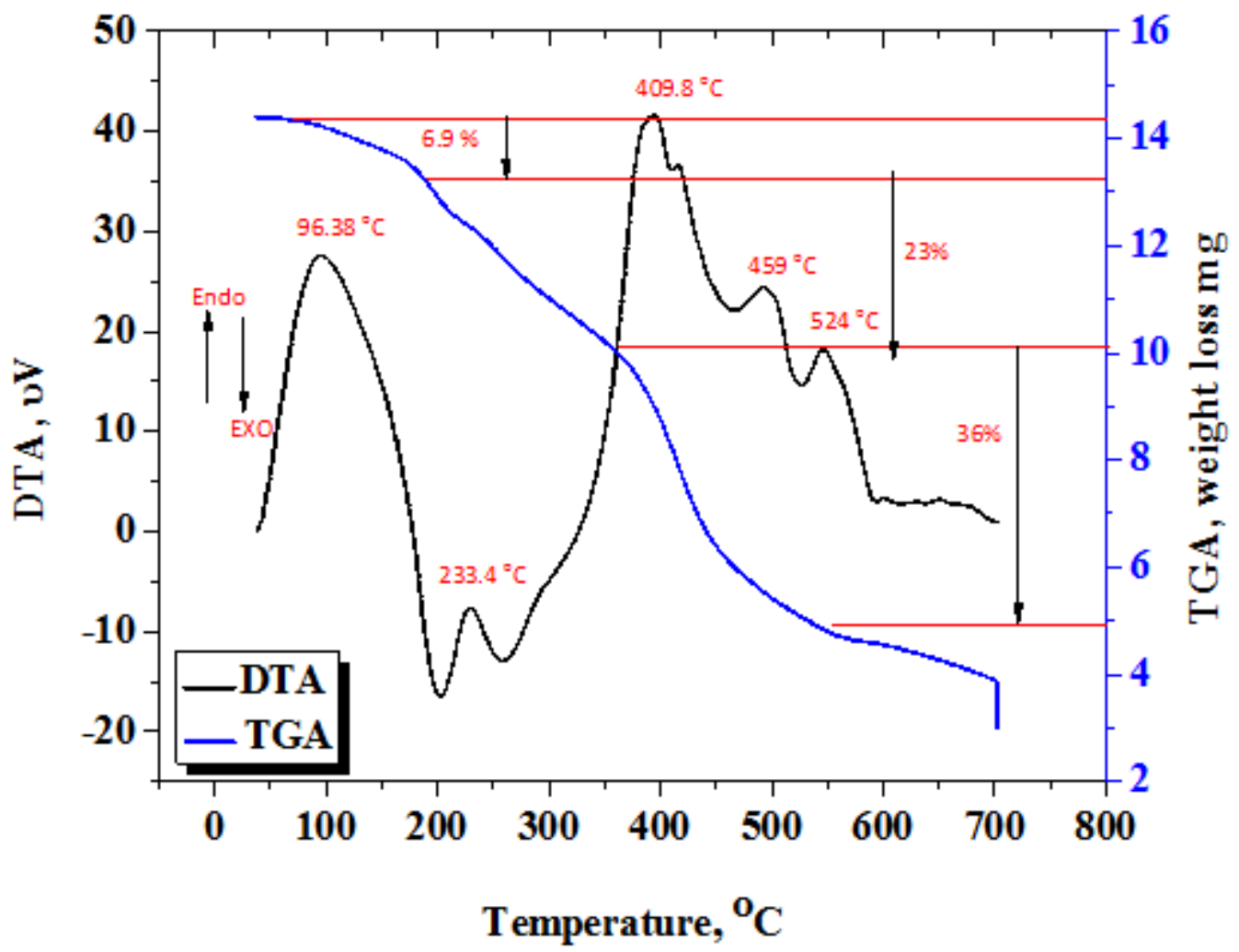

Figure 6 
DTA-TGA analysis of C6P(AAM-co-IA/TiO2) nanocomposite
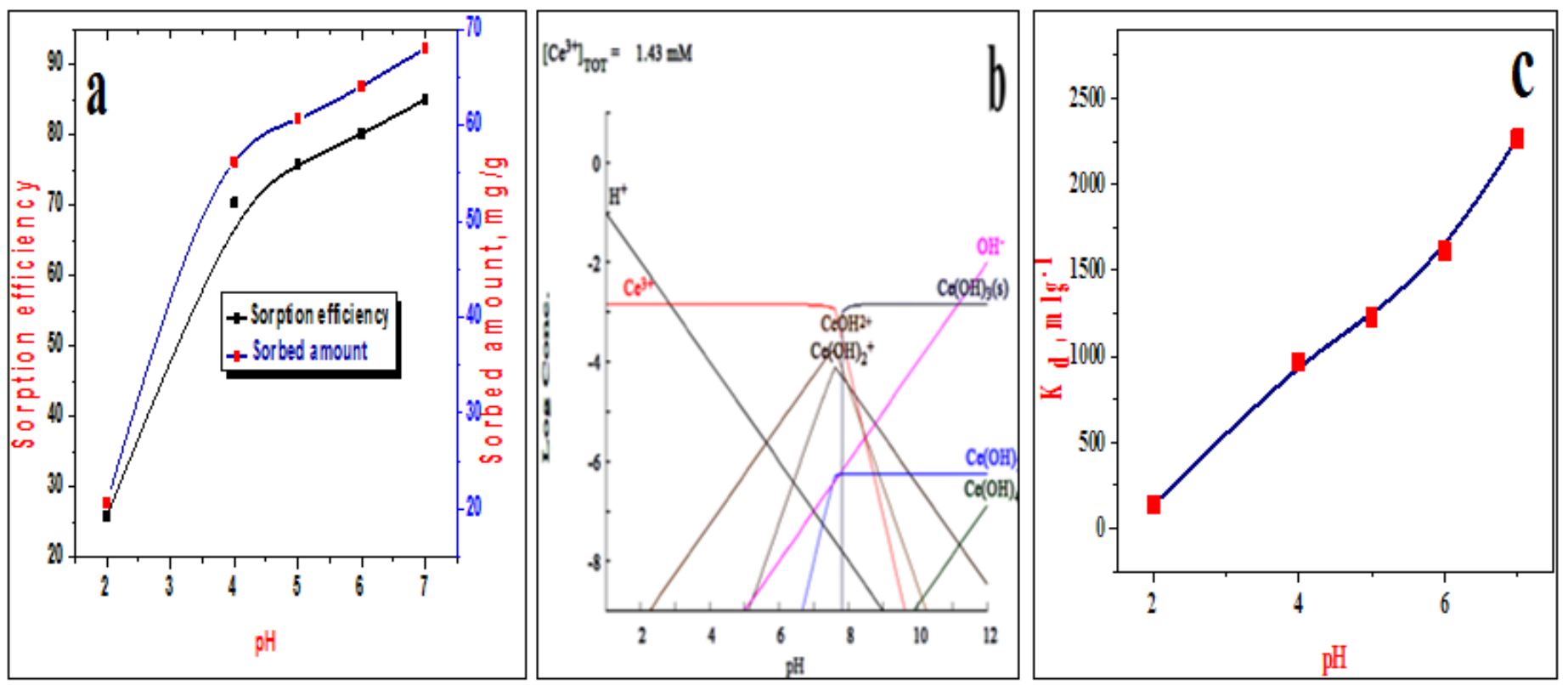

Figure 7

a- Sorbed amount and Sorption efficiency of Ce(III) onto C6P (AAM-co-IA/TiO2) composite at different pH b- Speciation diagrams for the $\mathrm{Ce}$ (III) ion c- Distribution coefficient of $\mathrm{Ce}(\mathrm{III}), \mathrm{Kd}, \mathrm{mLg}-1$ [ Co of $\mathrm{Ce}$ (III) $200 \mathrm{mgL}-1,298 \mathrm{~K}, \mathrm{~V} / \mathrm{m}=0.4 \mathrm{Lg}-1$, shaking time $=24 \mathrm{~h}]$

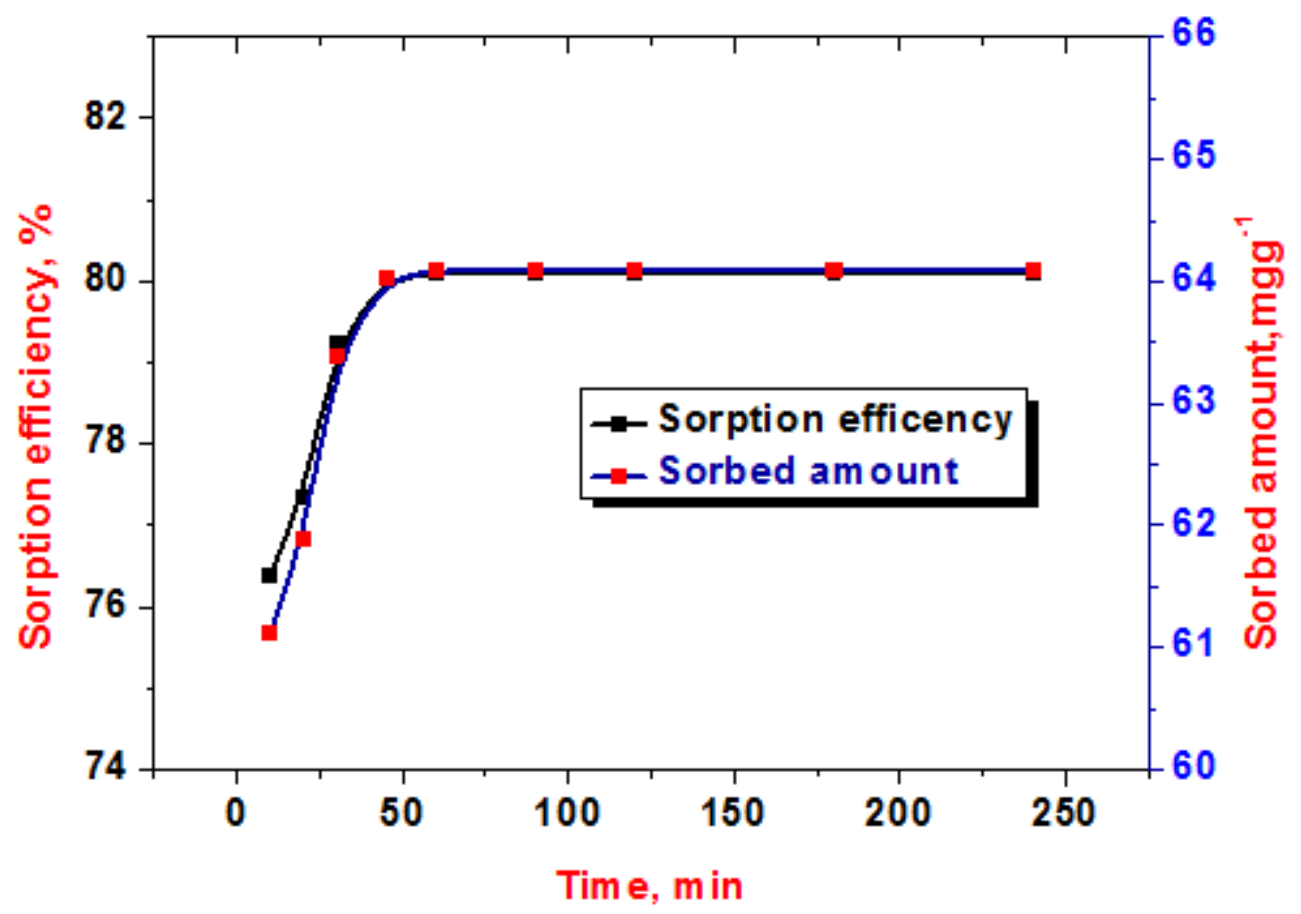

Figure 8 
Effect of contact time on the sorption efficiency and sorbed amount of Ce(III) onto C6P(AAM-co-IA/TiO2) nanocomposite [ Co of Ce(III) $200 \mathrm{mgL}-1,298 \mathrm{~K}, \mathrm{~V} / \mathrm{m}=0.4 \mathrm{Lg}-1, \mathrm{pH}=6$ ]

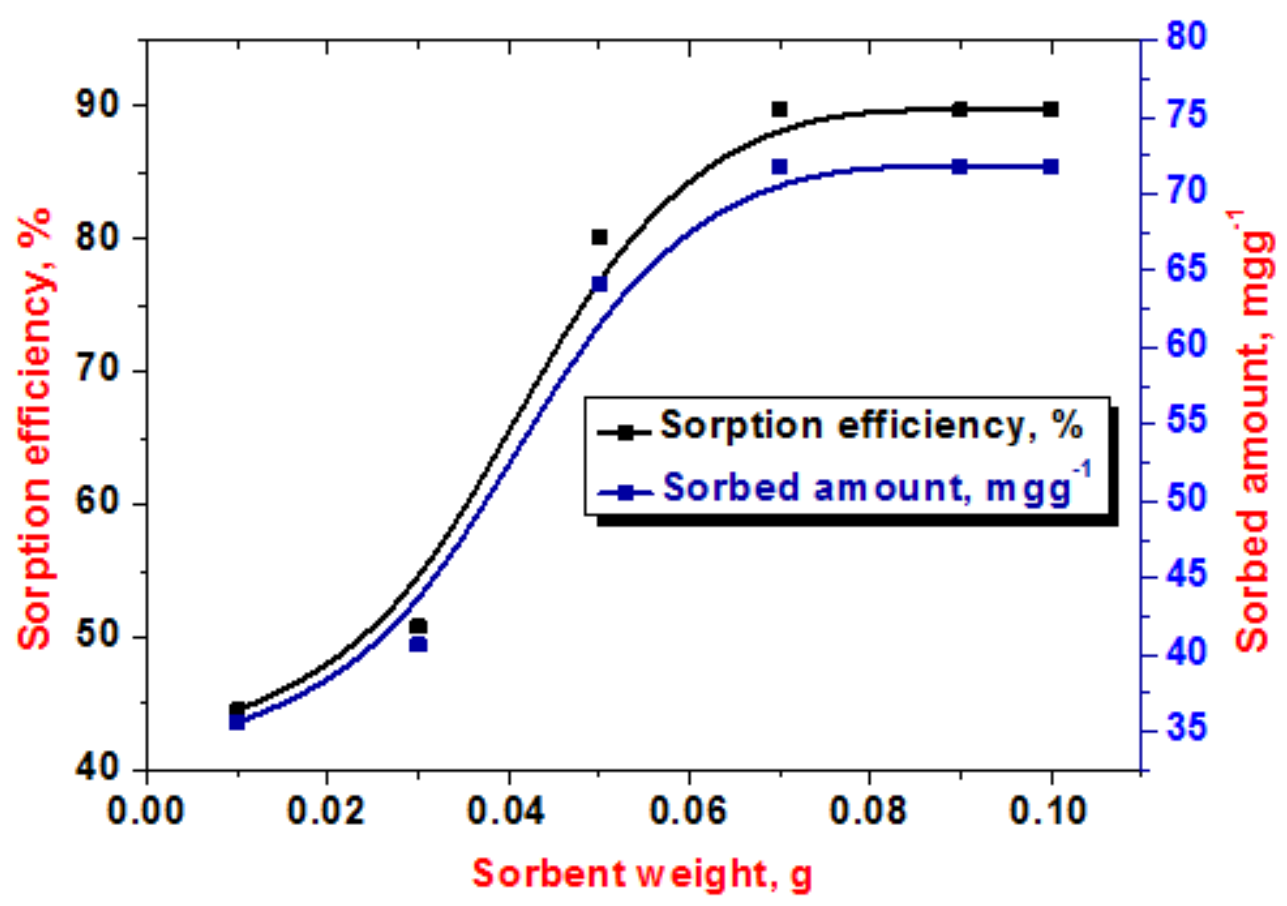

Figure 9

Effect of sorbent weight on the sorbed amount and sorption efficiency of Ce(III) onto C6P(AAM-coIA/TiO2) nanocomposite at [Co of $\mathrm{Ce}(\mathrm{III}) 200 \mathrm{mgL}-1,298 \mathrm{~K}, \mathrm{pH}=6$, equili. time $=60 \mathrm{~min}$ ]
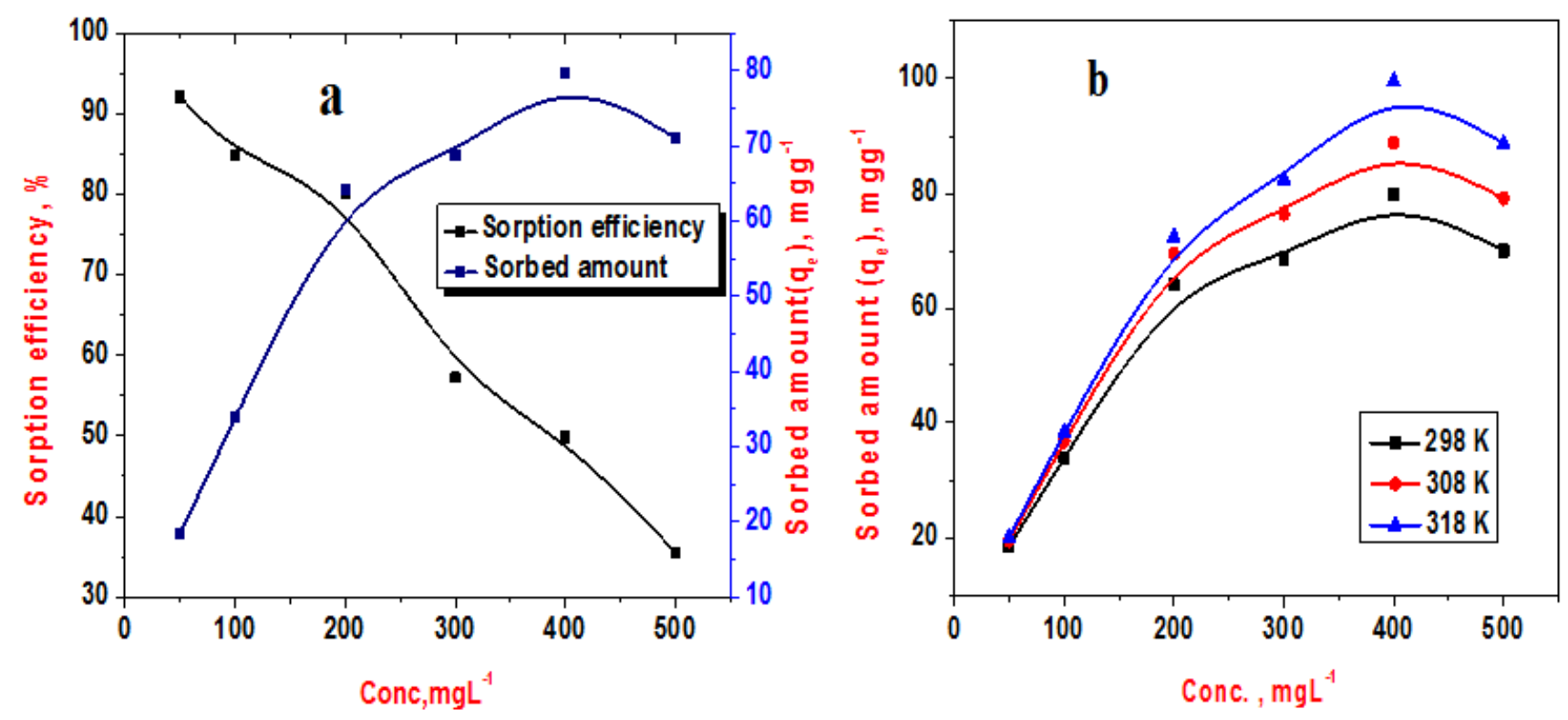

Figure 10 
Effect of initial concentration of $\mathrm{Ce}$ (III) on the sorbed amount and sorption efficiency, b- Effect of temperature on the sorbed amount of $\mathrm{Ce}(\mathrm{III})$ onto $\mathrm{C} 6 \mathrm{P}(\mathrm{AAM}-\mathrm{Co}-\mathrm{IA} / \mathrm{TiO} 2)$ nanocomposite $[\mathrm{V} / \mathrm{m}=0.4 \mathrm{Lg}-1$, $\mathrm{pH}=6$, equili. time $=60 \mathrm{~min}]$
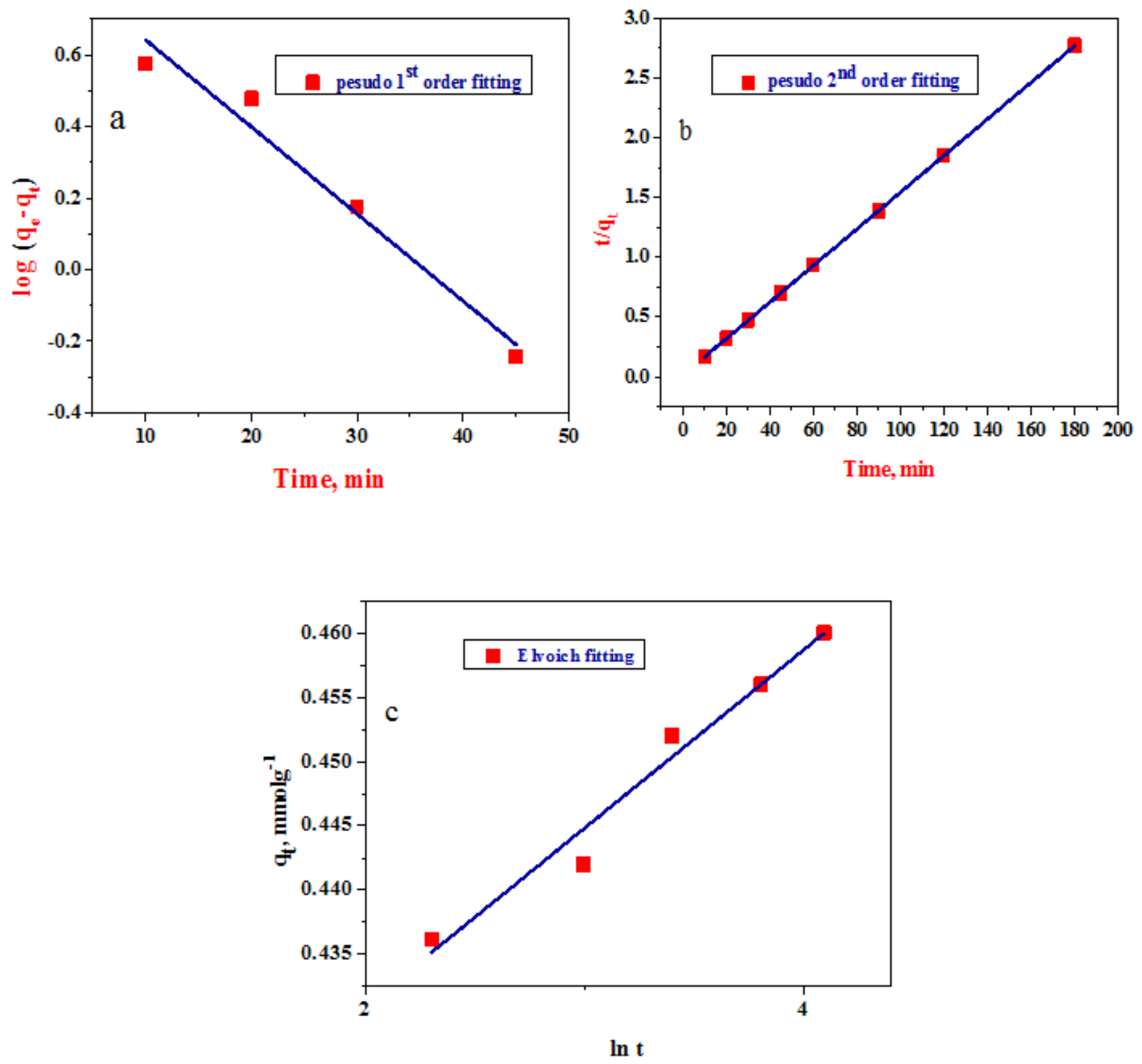

Figure 11

Kinetic models fitting for sorption of Ce(III) onto C6P(AAM-co-IA/TiO2) nanocomposite. a-pesudo1st order fitting b- pseudo 2nd order fitting c- Elvoich fitting [ Co of Ce(III) 200mgL-1 , 298K , V/m =0.4 Lg-1 , pH=6] 

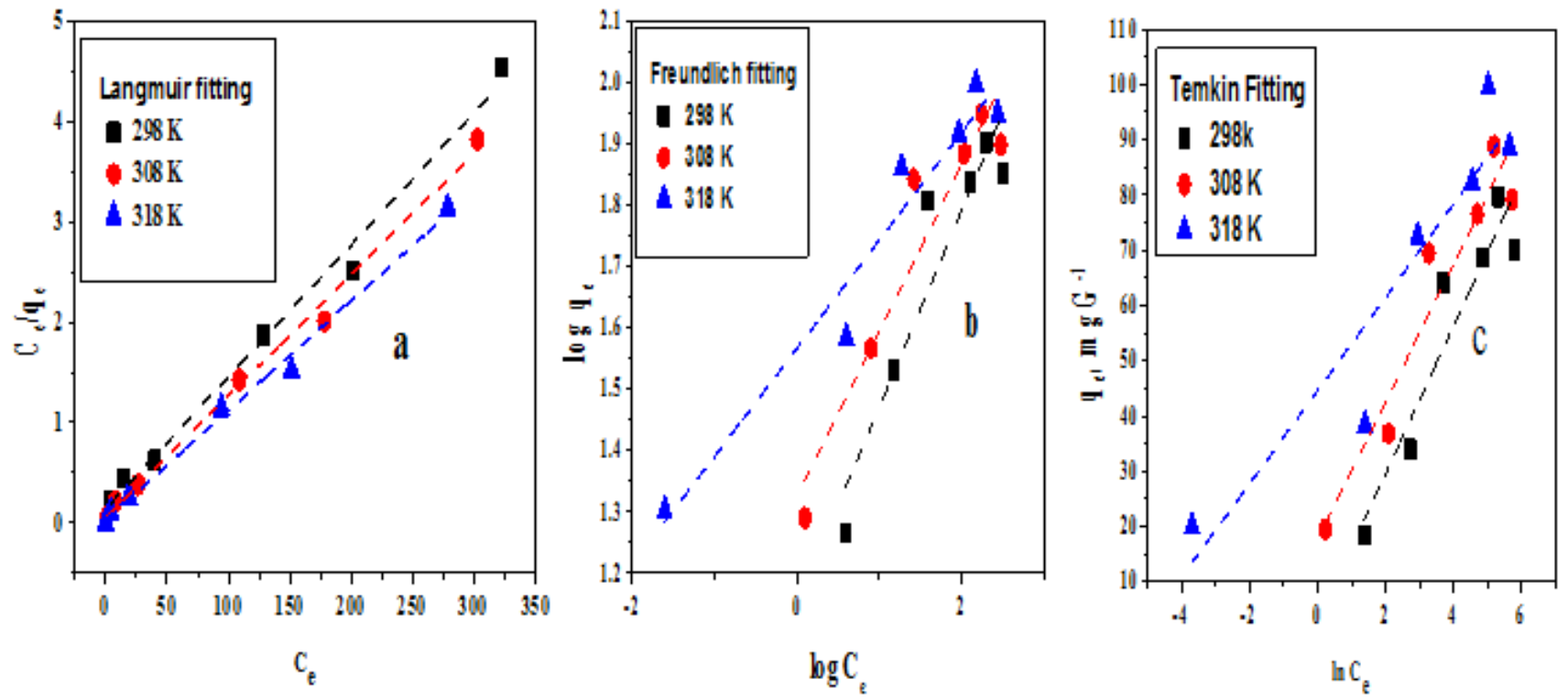

Figure 12

Isotherm models fitting for sorption of $\mathrm{Ce}$ (III) onto $\mathrm{C} 6 \mathrm{P}(\mathrm{AAM}-\mathrm{co}-\mathrm{IA} / \mathrm{TiO} 2)$ nanocomposite a- Langmuir fitting b- Freundlich fitting c- Temkin fitting [ $\mathrm{V} / \mathrm{m}=0.4 \mathrm{Lg}-1, \mathrm{pH}=6$, Eq. time $=60 \mathrm{~min}$ ]

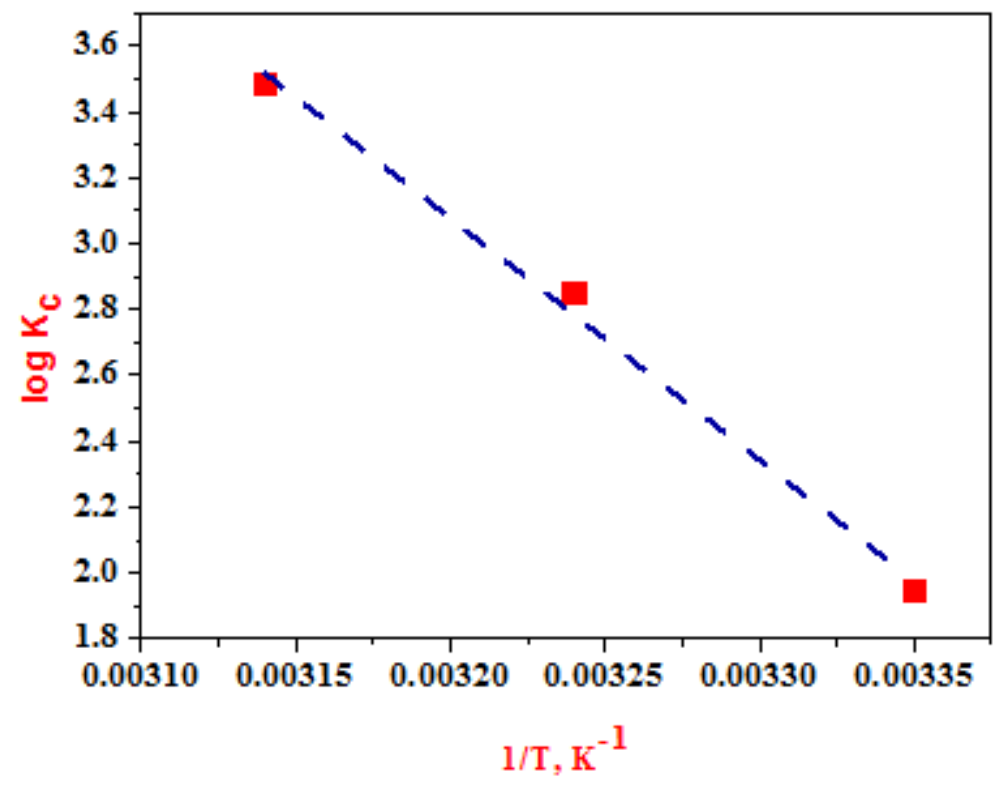

Figure 13

Thermodynamic plot for the sorption of $\mathrm{Ce}$ (III) onto $\mathrm{C} 6 \mathrm{P}(\mathrm{AAM}-\mathrm{co}-\mathrm{IA} / \mathrm{TiO} 2)$ composite $[\mathrm{pH}=6, \mathrm{v} / \mathrm{m}=0.4$ Lg-1 and Co of Ce(III) 200 mgL-1] 


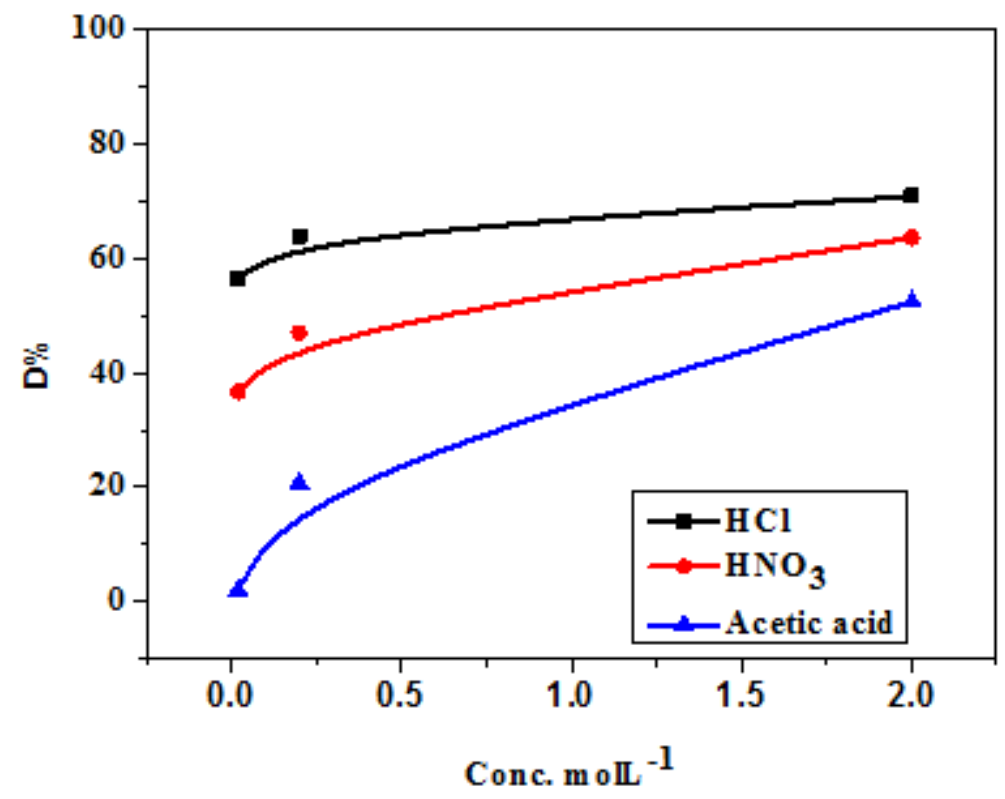

Figure 14

Desorption efficiency of loaded C6P(AAM-co-IA/TiO2) with different concentrations of $\mathrm{HCl}, \mathrm{HNO} 3$ and Acetic acid. [ V/m =0.4 Lg-1, contact time 24 hours, $298 \mathrm{~K}]$
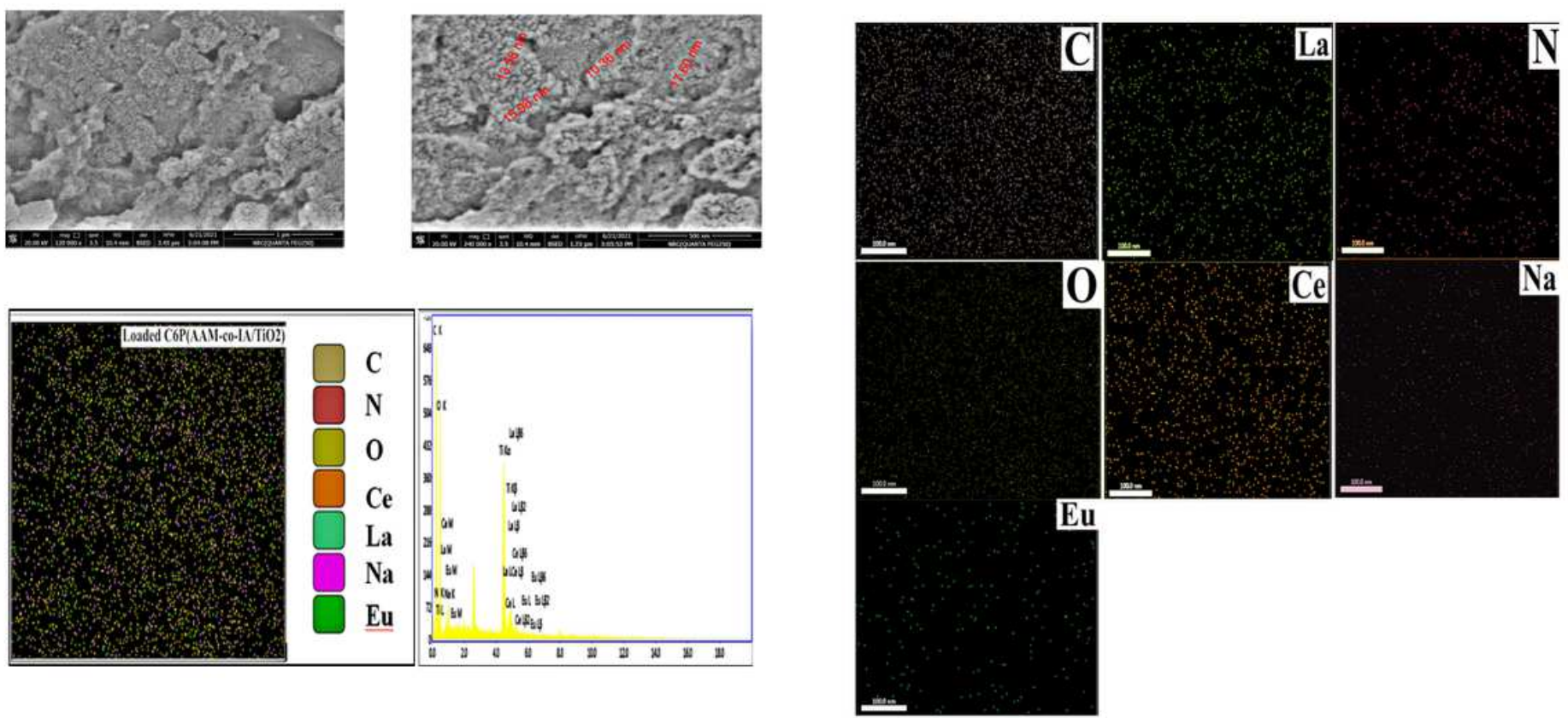

Eu

Figure 15

SEM of loaded P(AAM-co-IA/TiO2) nanocomposite with REEs after shaking with monazite solution for 2 hours at $298 \mathrm{~K}$

\section{Supplementary Files}


This is a list of supplementary files associated with this preprint. Click to download.

- Listoftables.pdf 